\title{
DRESS IN UPPER CANADA 1790-1840
}

\author{
By \\ Hannah Erika Milliken \\ Bachelor of Arts, Honours, With Distinction \\ University of Guelph, Guelph, Ontario, Canada, 2011-2015.
}

\begin{abstract}
A MRP
presented to Ryerson University

in partial fulfillment of the requirements for the degree of

Master of Arts

in the program of

Fashion
\end{abstract}

Toronto, Ontario, Canada, 2018.

(C) Hannah Milliken, 2018. 


\section{Author's Declaration}

I hereby declare that I am the sole author of this MRP. This is a true copy of the MRP, including any required final revisions.

I authorize Ryerson University to lend this MRP to other institutions or individuals for the purpose of scholarly research.

I further authorize Ryerson University to reproduce this MRP by photocopying or by other means, in total or in part, at the request of other institutions or individuals for the purpose of scholarly research.

I understand that my MRP may be made electronically available to the public. 


\author{
Abstract \\ Dress in Upper Canada 1790-1840 \\ Master of Arts, 2018 \\ Hannah Erika Milliken \\ Fashion, Ryerson University
}

This MRP aims to uncover unknown details of Canada's early dress history in the lives of early colonial settlers in Niagara and surrounding Upper Canadian settlements between 1790 and 1840. This study explores the access they had to goods and services, their loyalty to the imperial parent nation of Great Britain, and their adaptability to the conditions of a rudimentary frontier. The central conclusion is that relationships to fashion and dress were remarkably sophisticated in early Upper Canadian societies 


\section{Acknowledgements}

My sincerest thanks to my supervisor Alison Matthews David for all her help and guidance. I would like also to warmly thank Christina Smylitopoulos for her encouragement and inspiring enthusiasm for eighteenth-century studies. Special thanks to my Mum and Dad for their continuous support.

Hannah Milliken

April 2018 
INTRODUCTION: DRESS IN UPPER CANADA 1

LITERATURE REVIEW AND METHODOLOGY 28

CHAPTER 1. OBTAINABILITY: CONSUMPTION AND MATERIAL LIFE IN NIAGARA, 1790-1820

CHAPTER 2. LOYALTY: SIMCOE'S RANGERS AND DRESS IN UPPER CANADA, 17911796

CHAPTER 3. ADAPTABILITY: DRESS AND DOMESTICITY IN UPPER CANADA, 17901840

CONCLUSIONS AND OPPORTUNITY FOR FURTHER STUDY 


\section{List of Tables}

Table 1.1 Thomas Freel's Textile and Related purchases, September 1808 to May 1809...33

Table 1.2 Export of British Leather Manufacture, 1763-1778 and 1797-1805 (\%).........34

Table 1.3 Estimated English Shoe Export 1700-1800 (five year moving average)..........34

Table 3.1. The Complete List of the Price of Woman's Clothing for One Year, Hertfordshire

Parish, Britain 1796..........................................................69 


\section{List of Figures}

Figure 1. "Navy Hall, the part is the canvas house b) The fort at Niagara c) A large arbour in the Hill d) Toronto Shore.

Navy Hall, the part is the canvas Figure 2. "From the Camps on the heights above Queenstown" Elizabeth Simcoe (1766-1850).

Figure 3. Portrait of a Gentleman, Elizabeth Simcoe, ca.1793 .........................6

Figure 4. Men's Frock Coat, ca. 1770-1785 Britain.................................. 7

Figure 1.1. Locations of Mentioned General Stores and Urban Centres in Upper Canada, 18081817.

Figure 1.2. Gonder purchases of Coat Buttons, Silk and Thread, 1817....................31

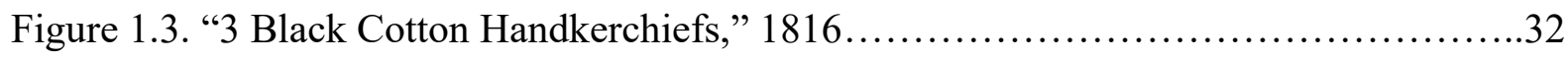

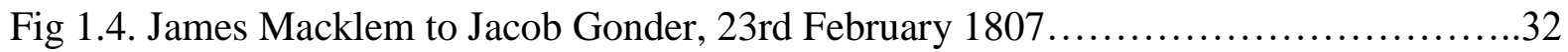

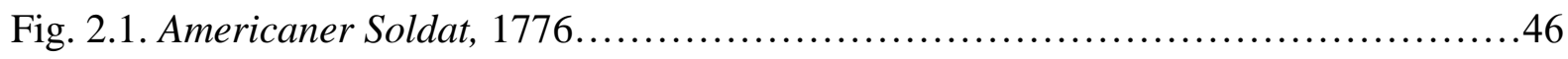

Fig. 2.2. William Jarvis Uniform, An Officer in the Queen's Rangers, 1791...............47

Fig. 2.3. Jean Laurent Mosnier, Portrait of Governor John Graves Simcoe. 1791............48

Figure 3.1. Child's leather stays, 1760-1780, Britain..............................61

Figure 3.2. Women's work clothing Short gown, America 1800-1820................62

Figure 3.3. Portrait of Elizabeth Posthuma Simcoe, c. 1799............................63

Figure 3.4. Maroon plain-woven worsted wool dress, 1820-1830, North America............64

Figure 3.5. Cotton Block Printed Textile, 1770-1790, England, United Kingdom.............65

Figure 3.6. Cotton Block Printed Textile, 1790-1800, England, United Kingdom.............65

Figure 3.7. Child's Frock, ca. 1790. Cotton manufactured in Britain, worn in America.......66

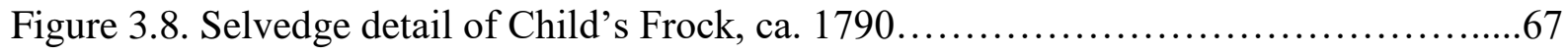

Figures $3.9 \&$ 3.10. Day Dress, Back (Left) and Front (Right) 1810-1815 silk.............68 


\section{Introduction: Dress in Upper Canada}

Elizabeth Posthuma Simcoe (1766-1850) arrived with her husband Governor John Graves Simcoe to Newark (Niagara on the Lake) on July 26th, $1792 .{ }^{1}$ An avid diarist, she took great stock of her surroundings during her time at Newark. She was also an avid sketcher and watercolourist who recorded the scenes around her. Many of her sketches survive, (Figures 1-3) providing a glimpse into the earliest days of settlement in the Niagara region. In Figure 1, Elizabeth illustrates the Newark landscape in 1793. Drawing from her canvas tent perched on the top of Queenston Heights, on the left is Navy hall, a government building used by British commanders, on the right is Fort Niagara, and in the rear left background is the Toronto lakeshore. Figure 2 depicts the canvas tents the Simcoe's brought with them from England for living in until accommodations could be built. The tents were transported back and forth between Toronto and Newark as the family journeyed between settlements. Elizabeth Simcoe cheerfully adapted to the tent shelters, while her husband complained that he was "miserably off for accommodation in this country and I am fitting up an old hovel that will look exactly like a carrier's alehouse in England when properly decorated and ornamented."2 Despite the rudimentary living conditions, Elizabeth Simcoe brought an extensive wardrobe with her from London, including ball gowns. ${ }^{3}$

Elizabeth wrote to her friend Mrs. Hunt from Niagara in February 1793 assuring her there are "many feathers, flowers and gauze dresses at our balls (which are every fortnight)." The

\footnotetext{
1 “Travels with Elizabeth Simcoe: A Visual Journey Through Upper and Lower Canada.” Archives of Ontario. 2012. Http://www.archives.gov.on.ca/en/explore/online/simcoe/simcoe-niagara-falls.(Accessed March 26 2018).

${ }^{2}$ Correspondence of Lieutenant Governor John Graves Simcoe, E.A Cruikshank, ed. (5 vols. Toronto, 2923-31). Vol 1. P. 205. As quoted in Mary Quayle Innis. Mrs. Simcoe's Diary. Toronto: Dundurn Press, 2007. P.23-24.

${ }^{3}$ Mary Quayle Innis. Mrs. Simcoe's Diary. Toronto: Dundurn Press, 2007. p.19.

${ }^{4}$ To Mrs. Hunt, Wolford Lodge, Devonshire, From Elizabeth Simcoe, Newark, February 1793. Elizabeth Simcoe and Mary Quayle Innis. Mrs. Simcoe's Diary. Toronto: Dundurn Press, 2007. pp. 119-120
} 
balls had suppers and tea, and "ornaments piled high on ladies' caps." Among the many sketches by Elizabeth Simcoe completed in Niagara is one she called "Portrait of a Gentleman" (Figure 3). The gentleman is spectacled and reading a paper. His pose is relaxed and casual. More than this, the gentleman is wearing a fashionable coat for men. The coat has slim arms with narrow cuffs, is cut away at the front and not buttoned up, with a high standing collar. This style of the coat was fashionable for men between 1785 and $1795 .{ }^{6}$ A frock of similar style and time period is held in the Winterthur Museum Collection, Winterthur, Delaware (Figure 4). The pale colour of the frock reflects the fashion for muted colours in menswear. ${ }^{7}$

The core motivation for this study is to further probe the evidence that there existed a fashionable society in Upper Canada. Having myself grown up in the Niagara region, Elizabeth Simcoe's diary and sketches challenged the vision I had of Upper Canadians being pioneers who were self sufficient and living off the land. Her records are what sparked research questions asking how clothing contributed to the shaping of the culture of early Upper Canada, and how the inhabitants of Newark and surrounding areas acquired clothing and what role it played in the days of early settlement. This MRP aims to uncover unknown details of Canada's early dress history in the lives of early colonial settlers in Niagara and surrounding Upper Canadian settlements. This study explores the access they had to goods and services, their loyalty to the imperial parent nation of Great Britain, and their adaptability to the conditions of a rudimentary frontier. The date range of this study is 1791 to 1840.1791 was the year the Province of Upper Canada was created, and 1840 rounds off the Rebellions of 1837-38. This range encompasses Upper Canada's early settlement history, a time period neglected by historians in favour of more

\footnotetext{
${ }^{5}$ Mary Quayle Innis. Mrs. Simcoe's Diary. Toronto: Dundurn Press, 2007. p. 26

${ }^{6}$ Linda Baumgarten. What Clothes Reveal: The Language of Clothing in Colonial and Federal America. The Colonial Williamsburg Collection. New Haven: Yale University Press, 2002. p.231

${ }^{7}$ Ibid. p.231.
} 
recent history. ${ }^{8}$ This MRP purposefully brings the early settlement era into view, beginning to uncover earlier roots of Canada's dress and material culture narrative. ${ }^{9}$

This MRP is structured thematically, with each chapter exploring a different concept or theme relating to dress in Upper Canada. Chapter 1 is an exploration of obtainability, in terms of access to dress and accessories in relation to the consumption patterns of rural Upper Canadian settlers in Niagara. Using archival material that includes data from ledgers belonging to Jacob Gonder from Chippewa, Niagara 1808-1817, it aims to illuminate the nature of clothing and textile consumption in rural Upper Canada, dismantling a common narrative in Canadian history literature that settlers were only spinning textiles at home, or that they were entirely selfsufficient. For comparison, additional data from Douglas McCalla's study Consumers in the Bush: Shopping in Upper Canada is examined, mainly account books from a Yonge Mills general store between 1808 and 1809. Both ledgers reveal types of textiles and materials available to rural Upper Canadians. Chapter 2 explores the idea of Loyalty in an early Upper Canadian political context and how the idea of Loyalty was reinforced through dress. Loyalty was the central idea that shaped political culture that was visually represented by the presence of Queen's Rangers, a British Militia regiment lead by John Graves Simcoe. The symbolism of the Queen's Rangers helped to visually establish and maintain power in Niagara's rigid British colonial society. Simcoe's vision for Upper Canada was a British imperial structure, deeply loyal to the Crown and committed to British values and institutions. ${ }^{10}$ The theme of adaptability finds its home in Chapter 3, which looks at the nature of women's lives through dress. It reviews the

\footnotetext{
${ }^{8}$ Douglas McCalla. Consumers in the Bush: Shopping in Rural Upper Canada. Montreal: McGill-Queen's University Press, 2015. P. 152

${ }^{9}$ Alexandra Palmer addresses this narrative from the mid-nineteenth century onwards in her volume Fashion: $A$ Canadian Perspective. University of Toronto Press. 2004.

10 David Mills. The Idea of Loyalty in Upper Canada, 1784-1850. Montreal and Kingston: McGill-Queen's University Press 1988. p.12.
} 
nature of the clothing and textiles available to women in Upper Canada and how they adjusted their domestic circumstances to the conditions of the settlement frontier. Using dress as the method of investigation, the scope of these three themes is meant to be a preliminary exploration into the complicated, rich and compelling lives of early colonial settlers. 


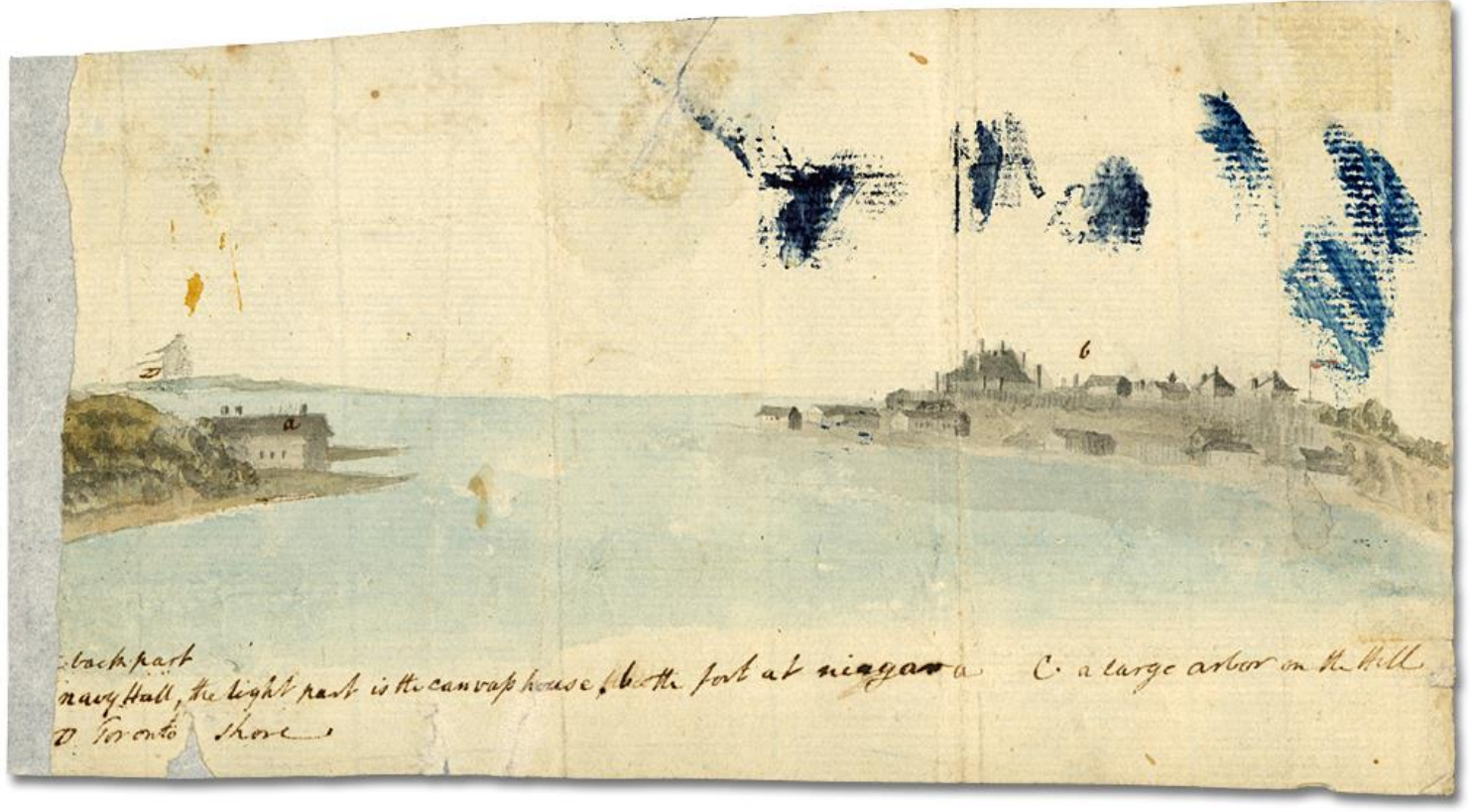

Figure 1. "Navy Hall, the part is the canvas house b) The fort at Niagara c) A large arbour in the Hill d) Toronto Shore." Elizabeth Simcoe, ca.1793. F 47-11-1-0-99 Archives of Ontario Visual Database, http://ao.minisisinc.com/scripts/mwimain.dll/ (Accessed March 26 2018).

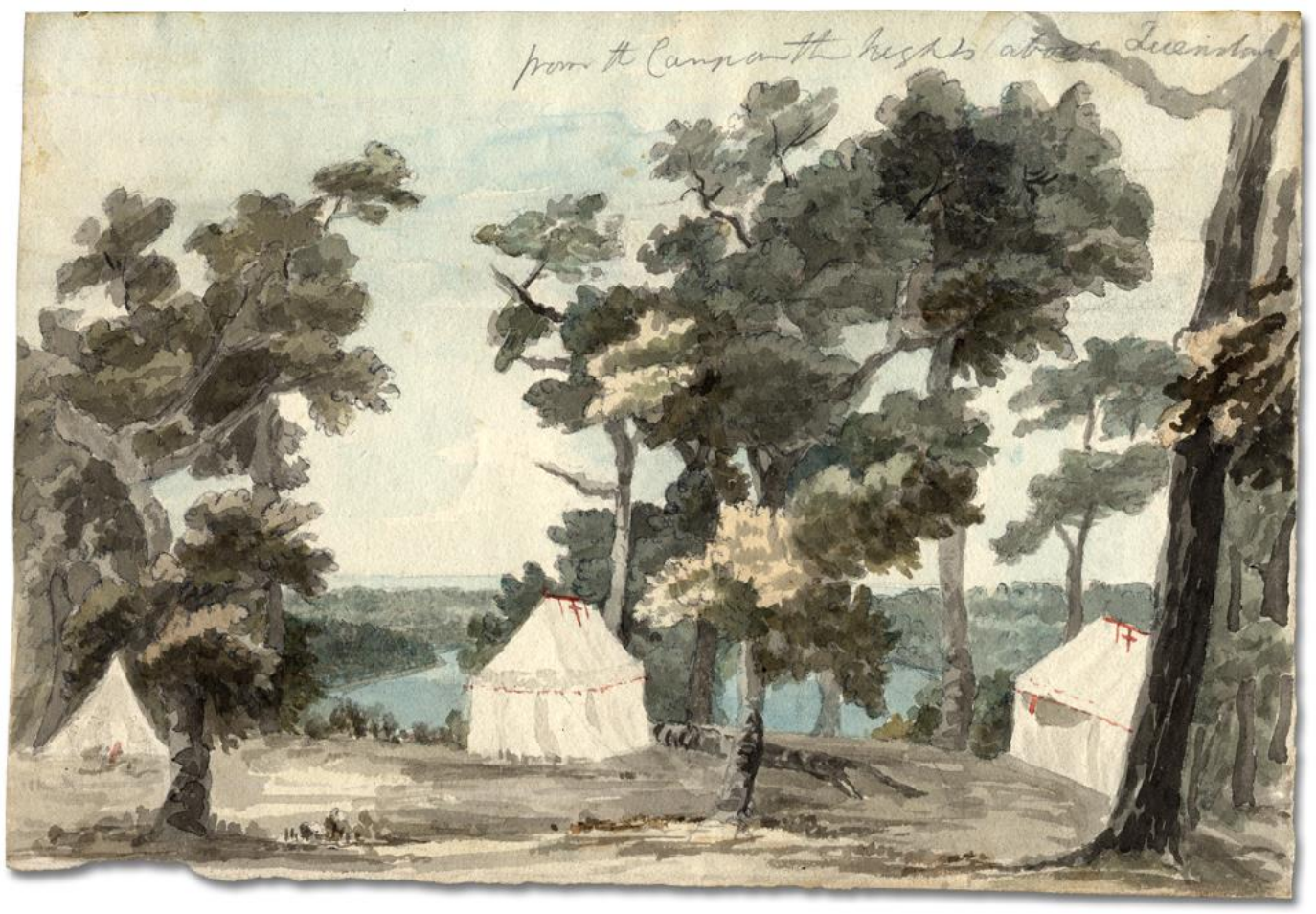

Figure 2. "From the Camps on the heights above Queenstown" Elizabeth Simcoe (1766-1850). July 9, 1793. F 47-11-1-0-90 Archives of Ontario Visual Database, http://ao.minisisinc.com/scripts/mwimain.dll/ (Accessed March 26 2018). 


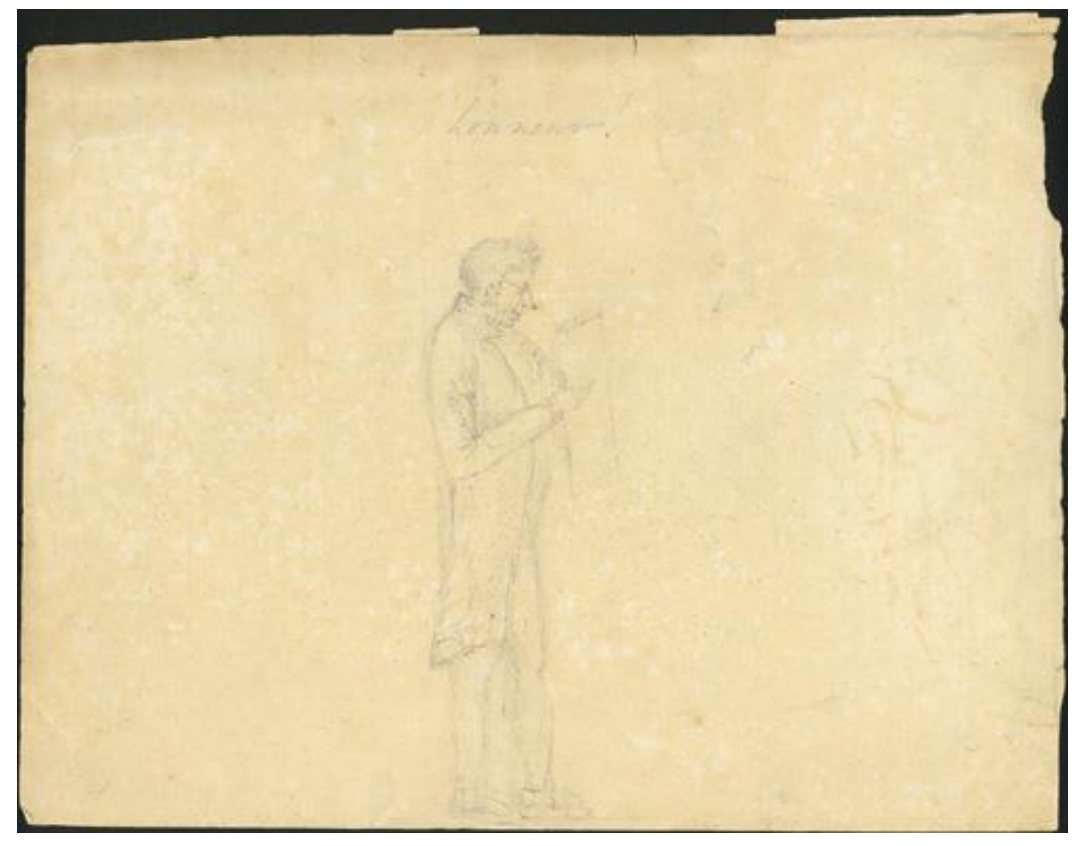

Figure 3. Portrait of a Gentleman, Elizabeth Simcoe, ca.1793. Archives of Ontario Visual Database, F 47-11-3-2. http://ao.minisisinc.com/scripts/mwimain.dll/ (Accessed March 26 2018). 


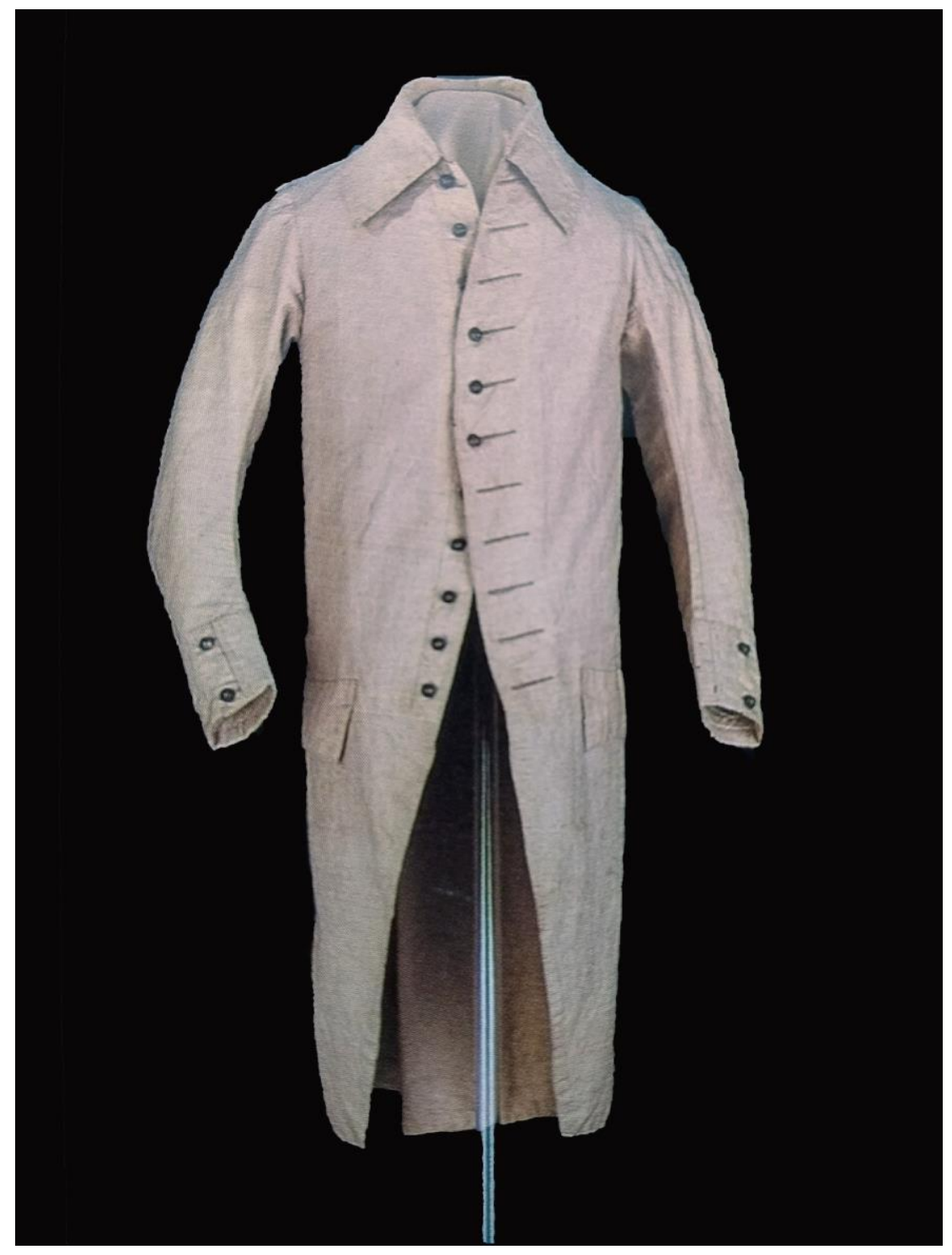

Figure 4. Men's Frock Coat, ca. 1770-1785 Britain, silk and worsted tabby trimmed with Sheffield-fused silver-plate buttons, lined with self-fabric and cotton, from the collection of Doris Langley Moore, Winterthur Museum Collection, Winterthur. Delaware. 1960-695. As reproduced in Linda Baumgarten, What Clothes Reveal: The Language of Clothing in Colonial and Federal America. The Colonial Williamsburg Collection. New Haven: Yale University Press, 2002. p.231. 


\section{Literature Review and Methodology}

The primary goal of this MRP is to uncover unknown details of Canada's early dress history. To represent the multiple avenues of investigation into dress, I have drawn from three fields of scholarship - material culture and consumption history, political history and women's domestic history and economy. In her book Fashion: A Canadian Perspective, Alexandra Palmer, Senior Costume Curator at the Royal Ontario Museum, highlights Canada's unique position as a location for dress history studies:

These histories, though centered in Canada, amplify the ongoing examination of fashion internationally and the unique position Canada holds within North America. Canada is sympathetic to and reliant upon the United States, while simultaneously allied to Europe and a colonial past - a situation that has rarely been discussed in this country in academic terms for fashion. ${ }^{11}$

Capitalizing on this unique position, this study aims to contribute to Alexandra Palmer's already decade-old work in Canadian fashion studies. With the goal of unravelling Canada's political and economic ties further, I have focused on a period in Canada's history not covered in Fashion: A Canadian Perspective - the late eighteenth to early nineteenth centuries. This was a tumultuous period in early Canadian history, which includes the War of 1812 and the Rebellions of 1837-38. Palmer's work is the beginning of a comprehensive national fashion history, examined through Canada's connections to other nations and multiple points of view. This study aims to contribute to this task by tackling a period roughly before Palmer begins her study - the late-eighteenth and early-nineteenth centuries. Like Upper Canadian material consumption historian Douglas McCalla states: "As the main chronological focus of Canadian historical research shifts ever farther forward in time, the settlement era can easily recede in historians' field of vision,

\footnotetext{
${ }^{11}$ Alexandra Palmer. Fashion: A Canadian Perspective. University of Toronto Press. 2004. p.11.
} 
becoming an abstract, timeless world "before" (for example, before markets or industrial capitalism or modernity)." ${ }^{\prime 2}$ This MRP purposefully brings the early settlement era to the forefront, demonstrating that people in late eighteenth and early nineteenth century Upper Canada were modern in the context of their times and fully participating in a greater global material culture narrative. ${ }^{13}$

Giorgio Riello highlights the usefulness of examining the "long eighteenth century" for dress history studies. Ranging roughly from 1660 to 1830 , the long eighteenth century in the United Kingdom encompasses the restoration of the British monarchy, the rise of the middle classes, modernization of retailing, manufacturing and the consumer revolution. ${ }^{14}$ This MRP falls into the tail end of the long eighteenth century framework. Not only is it a neglected time period in Canadian studies that requires closer attention, the historical themes it raises are ideal for dress history methodologies. Riello maintains that through the lens of the long eighteenth century, "the history of dress has emerged from being the Cinderella of academic research to recognition as a fundamental ingredient in the melting pot that combines 'classic' historical analyses, material culture studies, and object-based research." ${ }^{15}$ It is within this academic framework that I situate a multi-methodological dress history study during the period 1790-1840 in Upper Canada, with a focus on Niagara.

\section{Literature Review}

Due to the niche subject matter of Canada's early settlement history in Niagara, it is necessary to extrapolate information from scholarship dealing with dress in Britain, United

\footnotetext{
${ }^{12}$ Douglas McCalla. Consumers in the Bush: Shopping in Rural Upper Canada. Montreal: McGill-Queen's University Press, 2015. P. 152

13 Ibid. p. 152.

${ }^{14}$ Giorgio Riello. A Foot in the Past: Consumers, Producers and Footwear in the Long Eighteenth Century. Vol. 15. Oxford: Oxford University Press, 2006. P.7-8.

${ }^{15}$ Ibid. p.7-8.
} 
States, France and more populated centres in Upper Canada like Kingston. The problem of scarcity of sources characterizes the field of Canadian social history before 1830, with publications having to rely on histories and primary sources from Britain and the United States. ${ }^{16}$ However, data gleaned from Upper Canada's colonial ties in Britain and the United States are useful comparisons with archival material and Upper Canadians contexts. I have structured the following literature review in the same way as the body of my MRP - with each section covering subjects within the fields of material culture and consumption history, political history and women's domestic history and economy respectively.

\section{Obtainability: Consumption and Material Culture}

An outstanding example of a long eighteenth-century consumer study historian Giorgio

\section{Riello's A Foot in the Past: Consumers, Producers and Footwear in the Long Eighteenth}

Century. Riello approaches his study of footwear in terms of who wore it, who produced it, what was the significance of footwear and how widely available they were to European populations in the eighteenth century. ${ }^{17}$ In this MRP, I have applied those same research questions to Upper Canada in the late eighteenth century. Riello approaches footwear in social, cultural and economic terms, investigating how regional cultural contexts shaped the footwear needs of early modern Europe in an age of industrialization. Riello situates his work within the context of the evolution of the history of dress as a discipline over the last two decades, warning against the trend in fashion studies to focus on cultural, literary, and psychological analyses while neglecting art historical and object-based research. ${ }^{18}$ A Foot in the Past consciously sets an example of

\footnotetext{
${ }^{16}$ Two examples are Marjorie Griffin Cohen, Women's Work, Markets, and Economic Development in NineteenthCentury Ontario. Toronto: University of Toronto Press, 1988; and Jane Elizabeth Errington, Wives and Mothers School Mistresses and Scullery Maids: Working Women in Upper Canada 1790-1840. Montreal: McGill-Queen's University Press, 1995.

${ }^{17}$ Giorgio Riello. A Foot in the Past. p.5.

${ }^{18}$ Ibid. p.6
} 
successfully integrated traditional economic-history analyses with dress history methodologies. Another exemplary work combining traditional analyses with dress history methodologies is historian John Styles' The Dress of the People: Everyday Fashions in Eighteenth Century England. Styles poses similar research questions to Riello in terms of what ordinary people wore and owned, what is was made from, and what it was worth. ${ }^{19}$ Styles employs sources like the records of criminal trials and advertisements for fugitives to discover what people wore in eighteenth-century Britain. Alongside these records, Styles analyses paintings and textiles from the period to extrapolate how clothing looked. ${ }^{20}$ Dress of the People is also an excellent source for identifying specific eighteenth-century garments and the varied styles of dress among the working classes.

Specifically concerning dress in eighteenth-century North America, dress history and textile publications have covered the American colonies extensively in colonial centers like Williamsburg and Jamestown. ${ }^{21}$ Costume historian Diana De Marly’s Dress in North America is an excellent historical survey of the development of colonial textiles and fashions from 1492$1800 .{ }^{22}$ While providing excellent and detailed accounts of dress in the seventeenth centuries, De Marly's chapter on eighteenth century Canada is sparse, relying on the diaries of Irish topographer Isaac Weld, and portraits of leaders by prominent artists like Benjamin West and William Berczy. ${ }^{23}$ Born 1774, Weld travelled the United States and Canada for two years starting

\footnotetext{
${ }^{19}$ Styles, John. The Dress of the People: Everyday Fashion in Eighteenth-Century England. London: Yale University Press, 2007. pp.11-12.

${ }^{20}$ Ibid. p.11-12.

${ }^{21}$ Linda Baumgarten and Colonial Williamsburg Foundation. What Clothes Reveal: The Language Of Clothing in Colonial and Federal America. The Colonial Williamsburg Collection, Colonial Williamsburg Foundation, New Haven and London: Yale University Press, 2002; Montgomery, Florence M. Textiles in America 1650-1870... New York: W.W. Norton \& Co., 2007.

${ }^{22}$ Diana De Marly. Dress in North America: The New World 1492-1800. New York: Holmes \& Meier, 1990.

${ }^{23}$ Ibid. pp.157-162
} 
in $1795 .{ }^{24} \mathrm{He}$ noted in his travel accounts that although domestic manufacturing operations were in place throughout Canada, the majority of cloth supplies like linen and wool were imported from Britain. ${ }^{25}$ To that effect, De Marly employs the use of Exchequer Port Books, records that indicate exports and imports from shipping ports in Britain of cloth and clothing to Canada and American colonies. All exports listed in De Marly's appendix were British manufactures exported officially through the Port of London to places like Hudson's Bay and Nova Scotia in $1770 .{ }^{26}$ These records reveal the precise quantity of goods, trade developments, and range of specific materials. ${ }^{27} \mathrm{~A}$ separate ledger from 1770 records shipments to 'Canada' as a single entity, receiving among many other cloth types, 24,430 yards of flannel, costing $£ 1,973.5 \cdot 10 .{ }^{28}$ De Marly's section on Canada is the shortest in her chapter on eighteenth-century North America. Further interrogation into Canadian contexts using a wider range of research sources would fill gaps in this research. This MRP aims to act as the beginning stages of that research, taking some preliminary steps required for a more exhaustive look at Upper Canada's clothing history. Cory Willmott's "From Stroud to Strouds: The Hidden History of a British Fur Trade" is an excellent example of a study that traces the journey of textiles at the point of their manufacture in England to their circulation in indigenous and settler North America. ${ }^{29}$ It includes a map of trade routes and outposts, drawings of garment construction, clothing swatches, and shipping records. Willmott's methodologies and document sources are relevant to my study and serve as a model for the appropriate scope and findings.

\footnotetext{
${ }^{24}$ Thomas Seccombe. "Weld, Isaac (1774-1856)" Oxford Dictionary of National Biography. 2004. http://www.oxforddnb.com/index/101028984/Isaac-Weld

${ }^{25}$ Diana De Marly. Dress in North America: The New World 1492-1800. p.157.

${ }^{26}$ Ibid. pp.175-198.

${ }^{27}$ Ibid. p.198.

${ }^{28}$ Diana De Marly. Dress in North America: The New World 1492-1800. p.195.

${ }^{29}$ Cory Willmott. "From Stroud to Strouds: The Hidden History of a British Fur Trade Textile." Textile History 36, no. 2 (2005): 196-234.
} 
Upper Canada's political history was thoroughly examined by political historians during the 1980s and 1990s. Jane Errington's The Lion, The Eagle and Upper Canada (1994) is a study of the development of perceptions and ideologies in Upper Canada. Errington focuses on the period 1784-1828 to examine how leaders of Upper Canada viewed themselves and subsequently shaped the region's political identity. ${ }^{30}$ David Mills' The Idea of Loyalty in Upper Canada 1784-1850 as the titles implies, dissects the notion of loyalty, stating loyalty was the basis of political and societal legitimacy in Canada in first half of the nineteenth century. ${ }^{31}$ It is particularly revealing of central attitudes shaped by British Toryism and popular values like loyalty, order and stability. ${ }^{32}$ For example, during the election of 1800 , an anonymous speaker called "Cato" said to the electorate in York (Toronto): "I pause to admire and gratefully contemplate that noblest fabric of human wisdom, the British Constitution." ${ }^{33}$ Mills explains how debates over ideas of loyalty were publicly articulated through newspapers like the Upper Canada Gazette. ${ }^{34}$ Mills' work is crucial for my study as a source for identifying Upper Canadian political attitudes, as well as identifying the source of these attitudes in colonial centres like Britain and the United States throughout the eighteenth century.

The field of Upper Canadian history and has revealed evidence of widespread political engagement and the central role of the British government in all political affairs. It has also aimed to dismantle the heroic nature of Canadian historical narratives established in the nineteenth and early twentieth centuries, when, for example, "writers were especially fond of

\footnotetext{
${ }^{30}$ Jane Errington, The Lion, The Eagle and Upper Canada. A Developing Colonial Ideology. McGill-Queen's University Press, 1994. P. 10

${ }^{31}$ David Mills. The Idea of Loyalty in Upper Canada 1784-1850. McGill-Queen's University Press, 1988. p.5.

${ }^{32}$ Ibid. p.5.

${ }^{33}$ Upper Canada Gazette. 13 March 1800; in Edith Firth ed., The Town of York, 1783-1815. Toronto: Toronto University Press, 1962. p. 157. As quoted in David Mills. The Idea of Loyalty in Upper Canada 1784-1850. p.10.

${ }^{34}$ David Mills. The Idea of Loyalty in Upper Canada 1784-1850. p.10.
} 
claiming that colonists had been responsible for the successful defence of the province" during the war of $1812 .{ }^{35}$ This is particularly true in the case of George Sheppard's revisionist history Plunder, Profits and Paroles. Sheppard examines primary sources like garrison records, muster rolls, diaries and pension lists to uncover the true state of affairs behind official statements of wartime officials. ${ }^{36}$ Sheppard's work is representative of the shift in historical research towards a larger focus on primary sources and social and economic circumstances. While there is a trend toward a more social approach to Canadian history, clothing and dress is only considered alongside other social topics like diet, marriage and family - not as a productive method of analysis in its own right. By incorporating the Canadian histories mentioned with dress as the subject of focus, this MRP goes toward broadening the use of dress as a method for productive historical analysis.

Adaptability: Dress and Domesticity

Addressing women's lives in the eighteenth century, Amanda Vickery situates genteel British women as the fashioners of their own cultural lives, setting the precedent for a reexamination of the consumption practices and agency of prominent women before the Victorian age. ${ }^{37}$ Her evaluation of the nature of 'genteel' women's lives is a useful comparison to the lives of the colonial aristocracy that arrived in Upper Canada in the 1790s. Lou Taylor counts it as a "successful application of the new approaches to dress/textile history research," 38 whereas Aileen Ribeiro finds that Vickery's study lacks an "understanding of clothing in women's lives," 39 with

\footnotetext{
${ }^{35}$ Sheppard, George Christopher. Plunder, Profit, and Paroles: A Social History of the War of 1812 in Upper Canada. McGill-Queen's University Press, 1994. p.4.

${ }^{36}$ Ibid. p.4.

${ }^{37}$ Amanda Vickery. The Gentleman's Daughter: Women's Lives in Georgian England. New Haven, Conn: Yale University Press, 1999. pp. 1-2.

${ }^{38}$ Lou Taylor. The Study of Dress History. Manchester: Manchester University Press, 2002. p.74.

${ }^{39}$ Aileen Ribeiro, "Re-fashioning Art: Some Visual Approaches to the Study of the History of Dress" Fashion Theory 2 no. 4 (1998) p.325.
} 
less of a focus on clothing and more of a focus on "things." While clothing is not the main focus of analyses, Vickery presents the eighteenth-century genteel woman as a "manager of household consumption strategies." 40

As for literature concerning women specifically in Upper Canada, Errington's study Wives and Mothers, School Mistresses and Scullery Maids: Working Women in Upper Canada 1790-1840 is an important work that intends to remedy the fact that women are significantly absent from most histories of Upper Canadian life. ${ }^{41}$ She challenges the assumption that what has traditionally been considered “women's work” had little economic or social value, thereby beginning a discussion about the lives of colonial women in Upper Canada between 1790 and $1840 .^{42}$ Errington covers a range of topics, from marriage and reproduction to the nature of domestic and farm labour, to the lifestyle of the colonial aristocracy. Her date range traces the development of Upper Canadian society from the early days of settlement in Niagara and York to their evolution into urban centres. Marjorie Griffin Cohen's influential study Women's Work, Markets, and Economic Development in Nineteenth-Century Ontario specifically concerns women's economy, zeroing in on household economy and production. ${ }^{43}$ In her section on cloth and clothing in early nineteenth century Upper Canada, Cohen expounds on the resources and labour required for homespun textiles. In the early days of settlement, sheep could not easily be raised and therefore materials for cloth-making were not readily available. Cloth and clothing was imported until settlements were more established. ${ }^{44}$ Cohen structures her analyses in terms

\footnotetext{
${ }^{40}$ Ibid. p.75.

${ }^{41}$ Jane Elizabeth. Wives and Mothers School Mistresses and Scullery Maids: Working Women in Upper Canada 1790-1840. Montreal: McGill-Queen's University Press, 1995. p.xiii.

42 Jane Elizabeth. Wives and Mothers School Mistresses and Scullery Maids. pp. xiii-xiv.

${ }^{43}$ Marjorie Griffin Cohen Women's Work, Markets, and Economic Development in Nineteenth-Century Ontario. Toronto: University of Toronto Press, 1988. P. 3

${ }^{44}$ Marjorie Griffin Cohen Women's Work, Markets, and Economic Development in Nineteenth-Century Ontario. pp. 76-77.
} 
of household economy and market economy, women's labour and housework in Ontario, providing insights into the working lives of Canadian women.

\section{Linda Baumgarten's What Clothes Reveal: The Language of Clothing in Colonial and}

Federal America is a rich visual resource on surviving dress examples from America and Britain during the eighteenth and early nineteenth centuries. The study was based on the antique artifacts at the Colonial Williamsburg foundation in Williamsburg, Virginia, and includes a timeline for fashionable dress categorized by decade, which was useful for identifying the approximate year of Elizabeth Simcoe's portrait from $1799 .{ }^{45}$ In Upper Canada, Queen's University Collection of Canadian Dress at the Agnes Etherington Art Centre holds an example of a sumptuous gown from Kingston, dating 1810-1815 that shows evidence of fabric recycling and unpicking to fashion a newer style of dress. ${ }^{46}$ This evidence fits into the grander narrative presented by Errington and Cohen of skilled women making and mending their own clothes at home, but also producing garments for local retail markets.

\section{Gaps in the Field}

Niagara between 1790 and 1840 is a neglected area for study, with most Canadian historians preferring to focus on the nineteenth century onwards. ${ }^{47}$ This is likely in part due to the scarcity of written sources in the very early settlement days outside of official government documents. I have extrapolated from studies elsewhere in Upper Canada where sources specific to Niagara cannot be found. In this area I have relied heavily on Douglas McCalla's work Consumers in the Bush: Shopping in Rural Upper Canada. McCalla draws from the ledgers and

\footnotetext{
${ }^{45}$ Baumgarten, Linda. What Clothes Reveal: The Language of Clothing in Colonial and Federal America. The Colonial Williamsburg Collection. New Haven: Yale University Press, 2002. Pp. 222-237.

${ }^{46}$ MacKay, Elaine M. Beyond the Silhouette: Fashion and the Women of Historic Kingston. Kingston: Agnes Etherington Art Centre, 2007. p.24

47 Douglas McCalla. Consumers in the Bush. p. 152
} 
account books from general stores across Upper Canada between 1808 and 1861. The 30,000 transactions these accounts contain provide a real insight to the type, amount, quality and price of goods available to Upper Canadians as early as 1808 . His chapter on clothing and textiles suggests a narrative of relative choice and affordability in the type of textiles available. ${ }^{48}$ While no accounts from Niagara stores are examined, I have supplemented this gap with my own archival research with ledgers from Chippewa, Niagara from 1807-1817, recording the personal purchases of Jacob Gonder. While all three of the subject areas examined address clothing and dress as an important aspect in the lives of Upper Canadians, it is never the focus or method of inquiry. Employing clothing and dress more explicitly as a central methodology can lead to new avenues of discovery. Applying dress methodologies to the barely examined subject of early settlement Niagara opens up a needed conversation about Canada's early history.

\section{Methodology}

I limit my study to Upper Canada between the years 1790-1840, focusing on Newark, but including the rest of Upper Canada in my analyses. As for specific methodology, I have used two: archival research and image analysis. Reflecting the multi-methodological nature of this study, I have drawn from a variety of historical archival documents - including journals, letters, account books and ledgers - while actively incorporating visual examples of dress from this period. The archival collections I have consulted at the Archives of Ontario are the Gonder Family Fonds accumulated by the Niagara Historical Society, 1796-1850; Thomas Ridout Family Fonds, 1754-1829; and the Isaac Wilson Diaries, 1811-45. ${ }^{49}$ Jacob Gonder's account books dating from 1807-1817 show the clothing, textile and sewing supply purchases he made in

\footnotetext{
${ }^{48}$ Douglas McCalla. Consumers in the Bush. pp. 37-66.

${ }^{49}$ Gonder Family Fonds, 1796-1850. Archives of Ontario, F 1138-8, reel MS 193/17; Thomas Ridout Family Fonds, Archives of Ontario, Reel MS 537 (1); Isaac Wilson Diaries, 1811-1845 Archives of Ontario, reel MS 199 (5).
} 
Chippewa, as well as a selling agreement for six pairs of men's shoes. Isaac Wilson's diaries reveal the perspective of a newly arrived settler from England, eager to obtain land and become a farmer. He provides an overview of the conditions of early Upper Canada. The Ridout Family Fonds are an invaluable source on the war of 1812. Thomas Ridout and his two sons served in the British Militia, and their correspondence provides details of key battles and life for British soldiers in Upper Canada.

As for illustrations and artworks, one source I have used is the Archives of Ontario visual database to find their holdings of Elizabeth Simcoe's original watercolors and sketches of Upper Canada and a portrait of John Graves Simcoe from 1791. In 1998 Aileen Ribeiro called for a more art historical approach to the history of dress, identifying the tendency in the field to rely heavily on economic analyses: "In a work of art, more of the whole picture of clothed humanity is literally revealed; we can see details of the clothes themselves, how they "work" on the body, and what they signify with regard not just to sex, age and class, but to status and cultural aspirations." ${ }^{50}$ Ribiero's statement does not mention the nuances contained in actual material garments and the potential for productive analyses, however works of art carry weight and intellectual content to unravel. Her call for more art historical methodologies has since been answered in works like Giorgio Riello's A Foot in the Past.

As Fashion scholars Skov and Melchior acknowledge, ${ }^{51}$ dress and fashion studies bridge together different methodologies and conceptual frameworks to offer a rich interdisciplinary study. The multi-disciplinary nature of dress history has come about through developments in the humanities and social sciences beginning in the 1980s which were characterized by interpretive

\footnotetext{
${ }^{50}$ Aileen Ribeiro, "Re-fashioning Art: Some Visual Approaches to the Study of the History of Dress" p.320.

${ }^{51}$ Lisa Skov and Marie Riegels Melchior. "Research Approaches to the Study of Dress and Fashion." Creative Encounters, Copenhagen, 2008. p.3.
} 
approaches, and linked to post-modernist thought. ${ }^{52}$ These developments have cleared the way for dress and fashion studies to become a discipline in its own right, and characterized as inherently multi-disciplinary. ${ }^{53}$ Within the mixed methods research design as described by Creswell, he describes the strategy of using two different sets of research concurrently in order to provide a more thorough analysis of the research problem. ${ }^{54}$ Also within this strategy is what Creswell calls the "nesting" of one form of research within another larger form. ${ }^{55}$ In keeping with this approach, I have aimed to nest the primary research within secondary contextual research, embedding a micro view of specific material objects onto a macro view of grander cultural, economic and political issues.

To reflect the multi-disciplinary nature of dress history studies, I have structured this research project thematically. Each major chapter examines a different aspect concerning or related to dress in late-eighteenth and early-nineteenth Canadian contexts. For the case study method I rely on Robert Stake's publication The Art of Case Study Research ${ }^{56}$ According to Stake, a case study "is expected to catch the complexity of a single case... We look for the detail of interaction with its contexts. Case study is the study of the particularity and complexity of a single case, coming to understand its activity within important circumstances." ${ }^{, 57}$ Stake places major emphasis on the importance of data interpretation within the case study method. ${ }^{58}$ Following Stake's guidelines, each case study emphasizes clear data presentation and

\footnotetext{
52 Ibid. p. 9; Taylor, Lou. The Study of Dress History (Manchester: Manchester University Press, 2002).

${ }^{53}$ Lisa Skov and Marie Riegels Melchior. "Research Approaches to the Study of Dress and Fashion." p. 9; Taylor, Lou. The Study of Dress History.

${ }^{54}$ John W Creswell. Research Design: Qualitative, Quantitative and Mixed Method Approaches. Thousand Oaks, CA: Sage Publications. 2003. P. 16.

55 Ibid. p. 16.

${ }^{56}$ Robert E Stake. The Art of Case Study Research. Thousand Oaks, CA: Sage Publications. 1995.

${ }^{57}$ Robert E Stake. The Art of Case Study Research. p. xi.

${ }^{58}$ Ibid. p.8.
} 
interpretation. It is important to acknowledge, as Stake does, ${ }^{59}$ that case study analysis is greatly subjective and dependent on the interests of the researcher, time restrictions, and resources. To ensure my MRP stays within reasonable limits of interpretation, I have let the focus of my research questions guide my data collection in each question. That being said, the method lends itself to detailed analysis of the data presented, in order to uncover understanding within each unique case. The case study research method matches the goals of this MRP, to highlight the complexities of early Canadian history and discover patterns in archival data.

My theoretical framework falls under a social constructivist, mixed-methods approach as summarized by John W Creswell. ${ }^{60}$ This approach relies on collected data - text, image and dress analysis, historical personal data, diaries, anecdotes, primary sources - to develop a theory or pattern that might emerge from extended research. It takes the stance that meaning is varied and complex, and directed towards certain objects or things that can be studied. ${ }^{61}$ My role as a researcher is to uncover complexity of views and circumstances rather than reducing meanings into categories. As Creswell describes, my goal is to rely on the personal experience and understanding of the individual, under the assumption that meaning is subjectively formed through historical and cultural processes that operate in the lives of the individuals studied ${ }^{62}$ The thematic structure of this MRP is ideal for this framework, as it allows for intimate examinations of people, places and things within the contexts of their time, and within a thematic structure. This framework involves a good foundational knowledge and understanding of the social, political, economic systems in late eighteenth-century Upper Canada, through which dress

\footnotetext{
${ }^{59}$ Robert E Stake. The Art of Case Study Research. p.77.

${ }^{60}$ John W Creswell. Research Design: Qualitative, Quantitative and Mixed Method Approaches. Thousand Oaks, CA: Sage Publications. 2003. p.8.

${ }^{61}$ Ibid. pp.8-9.

${ }^{62}$ John W Creswell. Research Design: Qualitative, Quantitative and Mixed Method Approaches. p.8.
} 
experience can be put into context. As well as examining dress experience within broader contexts, this MRP is simultaneously aiming to do the reverse - provide new insights into political and social structures through an analysis of dress. 


\section{Chapter 1}

Obtainability: Consumption and Material Life in Niagara, 1790-1820

Isaac Wilson arrived in Little York (Toronto) from Cumberland County, England in

1811, preceding his father who was to follow him a little more than a year later. ${ }^{63} \mathrm{He}$ served in the British militia in the War of 1812 and fought at the first battle of York. Isaac would eventually become a farmer. ${ }^{64}$ On the 19 th of November 1811 , Isaac wrote to his parents to let them know he had landed safely. He also gave a general report on life in Little York:

By your account iron is here 1s per pound which high wages they have makes all articles made of it very dear; an axe about 4 pounds weight is from 20 s to 3 dollars, beef is from $5 \mathrm{~d}$ to $6 \mathrm{~d}$. Mutton is from $8 \mathrm{~d}$ to $9 \mathrm{~d}$ pork butter $1 \mathrm{~s} 6 \mathrm{~d}$ cheese $1 \mathrm{~s}$ per pound new milk $6 \mathrm{~d}$ per quart wheat 1dollar corn $6 \mathrm{~s}$ oats $3 \mathrm{~s}$ per bushel. A good horse from 50 to 60 dollars a cow about 20 . Labourers by the month from 12 To 20 dollars with victuals. They work from sun rise to sun set by the day $8 \mathrm{~s}$ in summer, 5 in winter. I mean New York currency all along. Shoes are from 2 dollars to 20s. But they are very little worth, if any of you come over bring a good supply with you and two or three pair of new clogs. I regret the want of them most of anything. The roads are very dirty... ${ }^{65}$

Wooden Clogs were the preferred footwear of working people in Britain throughout the eighteenth and nineteenth centuries, widespread especially in the northern counties. ${ }^{66}$ The wooden soles kept feet up and out of the mud, which was ideal for farm labour and country roads. Coming from Cumberland County, Isaac Wilson mourned the absence of the practical shoe he likely wore while working at home. By 1812, the population of the Province of Upper

\footnotetext{
${ }^{63}$ Colin Read. Rebellion of 1837 in Upper Canada. Vol. 134 of Carleton Library Series. McGill-Queen's Press, 1988. P. 417.

${ }^{64}$ Colin Read. Rebellion of 1837 in Upper Canada. p. 417.

${ }^{65}$ Isaac Wilson to Mr. and Mrs. Wilson, November 19 1811. Isaac Wilson Diaries, Archives of Ontario, reel MS 199 (5). Isaac Wilson writes in terms of American dollars within British pounds, shillings and pence. Upper Canada's currency system before 1812 was a muddled confusion due to not having a currency of its own. The colony used both American dollars and English shillings and even Spanish "half-joes." Pounds, shillings and pence had a consistent relationship of 12 pence to the shilling and 20 shillings to the pound. George Christopher Sheppard. Plunder, Profit, and Paroles: A Social History of the War of 1812 in Upper Canada. McGill-Queen's University Press, 1994; Clive Emsley, Tim Hitchcock and Robert Shoemaker. "Currency, Coinage and Cost of Living" Old Bailey Proceedings Online. www.oldbaileyonline.org, version 7.0, 24 (Accessed March 24 2018).

${ }^{66}$ Giorgio Riello. A Foot in the Past: Producers and Footwear in the Long Eighteenth Century. Vol. 15. Oxford: Oxford University Press, 2006. p.34.
} 
Canada had reached 100,000, with the majority living in rural conditions. ${ }^{67}$ Douglas McCalla's 2015 study Consumers in the Bush: Shopping in Rural Upper Canada examines the ledgers and account books from rural general stores in Upper Canada throughout the nineteenth century. For our purposes, the most useful ledger belonged to Charles Jones (1781- 1840), who owned a store and a milling complex in Yonge Mills, Leeds County. ${ }^{68}$ Jones was a member of a prominent Loyalist family in the area and later became involved in business and politics ${ }^{69}$ The ledgers date from September 1st 1808 to August 31st 1809. They provide a valuable glimpse into the consumption patterns and material life of rural Upper Canadians, most of whom at this time were farmers, artisans, labourers and rural entrepreneurs. ${ }^{70}$ The ledgers also convey information about Upper Canada's rural economy - the details of transactions and circulation of goods. McCalla argues that it is crucial to include rural areas in the story of early Upper Canada consumption history, as the goods people were purchasing provide valuable clues to lifestyle and what they were doing, wearing and eating. ${ }^{71}$

This chapter will examine relevant eighteenth and early -nineteenth century clothing and material consumption patterns as previously analyzed in studies by Douglas McCalla for Upper Canada and Giorgio Riello for Britain and France, ${ }^{72}$ and extrapolate their analysis to data and letters from people living in Niagara around the same time. Specifically, it will compare data compiled by McCalla from Charles Jones' ledger from 1808-1809, with account books belonging to Jacob Gonder dating from 1807-1817, in Chippewa, Niagara,

\footnotetext{
${ }^{67}$ David Mills, The Idea of Loyalty in Upper Canada, 1784-1850. p.21.

${ }^{68}$ Douglas McCalla. Consumers in the Bush: Shopping in Rural Upper Canada. Vol. 3;3. Montreal and Kingston: McGill-Queen's University Press, 2015. P. 3.

${ }^{69}$ Ibid. p.3.

${ }^{70}$ Ibid. p.3.

${ }^{71}$ Ibid. p. 5.

${ }^{72}$ Douglas McCalla. Consumers in the Bush; Giorgio Riello. A Foot in the Past.
} 
retrieved from the Archives of Ontario. ${ }^{73}$ It will also look at references to clothing and shoes in surviving Niagara correspondence dating from 1790-1812.

Douglas McCalla's chapter Fashion in the Countryside? Textile and Clothing Purchases considers the accuracy of the 'homespun' narrative in Canada's textile history literature. ${ }^{74} \mathrm{~A}$ common thread in Canadian settler history is the romanticized notion that rural people in Upper and Lower Canada produced the entirety of their own fabric themselves, and did not shop or buy fabric. Dismantling this notion, McCalla presents the case of farmer Thomas Freel's account at Jones' Yonge Mills store, between 1808 and1809 (Figure 1 shows the location of Yonge Mills and Chippewa on a general map of Upper Canada). Thomas Freel's account tells us much about the frequency of textile and clothes-making related purchases that occurred in rural areas of Upper Canada (Table 1.1). Thomas Freel had a family of seven to provide clothes for, and twenty acres of farmland. ${ }^{75}$ On Freel's account are transactions for the purchase of ten different fabrics, including flannel, woolen cloth, velvet, Lancashire sheeting, cotton, calico, linen, and cambric, totalling over 73 yards. ${ }^{76}$ As for ready-made items, the Freels bought a pair of gloves, two handkerchiefs, three shawls, a blanket and two hats. The number of ready-made items the Freels purchased in a year is few compared with the frequency of items that indicate most of the clothing was being sewn at home. For instance from September 1808 to May 1809, the Freels bought thread eleven times, a thimble, needles and pins, ribbons, and silk thread. ${ }^{77}$ Home-dying was taking place as well - on November 1st 1808 the Freels purchased indigo for $\$ 3.20$.

\footnotetext{
${ }^{73}$ Gonder Family Scrapbooks, Gonder Family Fonds, 1796-1850. Archives of Ontario, F 1138-8, reel MS 193/17.

${ }^{74}$ Douglas McCalla cites Adrienne Dora Hood, and David-Thiery Ruddel, "Artifacts and Documents in the History of Quebec Textiles." In Living in a Material World: Canadian and American Approaches to Material Culture , edited by Gerald L. Pocius, 55-91. St John's: Institute of Social and Economic Research, Memorial University, 1991, as a prominent example of the homespun narrative. Douglas McCalla. Consumers in the Bush. p. 38.

${ }^{75}$ Douglas McCalla. Consumers in the Bush. p. 46.

${ }^{76}$ Ibid. p. 46.

${ }^{77}$ Ibid. p. 46.
} 
Especially for large families with large accounts such as the Freels, McCalla notes large patterns of fabric and sewing was typical, and suggests a different narrative rather than homespun rural isolation. ${ }^{78}$ Frequent transactions too, suggests an idea of "shopping" as a regular occurrence. Jacob Gonder, son of Michael Gonder, belonged to a loyalist family from Pennsylvania who came to the Niagara region during the American Revolution. ${ }^{79} \mathrm{He}$ lived in the village of Chippewa, a village between Niagara Falls and Fort Erie (Figure 1.1). His surviving account books reveal purchases that align with Thomas Freel's. The proprietor, Charles Jones, who owned a store in Yonge Mills in 1808, also owned a milling complex along with another store in the area. ${ }^{80}$ Such was likely the case in Chippewa, as the records indicate Jacob's goods were "bot of Clark and Street" [sic]. Samuel Street was a United Empire Loyalist of English descent, who, along with together with Thomas Clark, owned several grist and sawmills in the Niagara region, and as the Gonder records indicate, at least one store. ${ }^{81}$ Gonder's accounts show purchases of darning needles, which suggests his clothes were being mended at home, coat buttons, even velvet ribbon. ${ }^{82}$ Like the stores in Yonge Mills, the stores in Chippewa sold ready-made items, with handkerchiefs being the most popular items from McCalla's study in 1808-09. Thirty-two of the handkerchiefs purchased that year cost 75 cents or less. ${ }^{83}$

The availability and variety of fabrics available in rural areas as early as 1808 suggests a narrative of relative sartorial freedom. Britain was consistently exporting textiles to Upper and

\footnotetext{
${ }^{78}$ Douglas McCalla. Consumers in the Bush. p. 46.

79 "The Loyalist Collection" UNB Libraries, 2018. University of New Brunswick, https://loyalist.lib.unb.ca/node/4204 (Accessed March 2 2018).

${ }^{80}$ Douglas McCalla. Consumers in the Bush. p. 3.

${ }^{81}$ Swainson, Donald. "Street, Thomas Clark (Clarke)" 1972. Dictionary of Canadian Biography. http://www.biographi.ca/en/bio/street_thomas_clark_10E.html (Accessed March 1 2018); Gonder Family Scrapbooks, Gonder Family Fonds, 1796-1850. Archives of Ontario, F 1138-8, reel MS 193/17.

${ }^{82}$ Specifically, figure 1.2 shows Gonder purchasing 9 coat buttons, 5 yards whole leather, and thread on September 1st 1817. In 1816 Gonder bought 3 black cotton handkerchiefs, several yards of cotton and several yards of silk (Figure 1.3.)

${ }^{83}$ Douglas McCalla. Consumers in the Bush. p.57.
} 
Lower Canada. Montreal merchants supplied rural retailers with imports from Britain, luxury fabrics included. ${ }^{84}$ Charles Jones, the Yonge Mills proprietor, imported approximately 8,100 yards of forty different fabrics to sell at his stores in 1808 which included velvet, taffeta and velveteen. ${ }^{85}$ These range in quality and expense: velveteen was an inexpensive all-cotton fabric with a close filling pile cut to look like velvet, while taffeta was a luxurious fabric made of silk for women's wear. ${ }^{86}$ This evidence suggests that Charles Jones was consciously importing textile goods to serve families with varying incomes. His customers must have had interest in fashionable textiles or fashionable clothes-making even in a rural area such as Yonge Mills. Textile shipments from Britain reached Upper Canada seasonally, and were shipped up the St. Lawrence River from Quebec between late July and early November, while shipments to Niagara came by lake boats constructed at Kingston, travelling on Lake Ontario. ${ }^{87}$ In McCalla's study, by far the leading fabric imported and sold in Upper Canada was cotton, followed by wool. Of the 8,100 yards of imported fabric, $70 \%$ of it was cotton, followed by 1,500 yards of woolens, 1,600 yards of linen and 800 yards of mixed fabrics, and 220 yards of luxury fabrics ${ }^{88}$ All this was available due to Britain's industrial productivity which was well established by 1808 , with rapid expansion and industrialization of cotton production at the forefront. Britain also supplied the goods necessary for the success of a general store and clothes making at home, like sewing supplies and mending materials. ${ }^{89}$

\footnotetext{
${ }^{84}$ Douglas McCalla. Consumers in the Bush. p.44 \& 48.

${ }^{85}$ Ibid. p.48.

${ }^{86}$ Isabel B. Wingate. Fairchild's Dictionary of Textiles, Sixth Edition. New York: Fairchild Publications, 1979. p.652 \& 599 .

${ }^{87}$ Mary Holford. "Dress and Society in Upper Canada, 1791-1841." Costume 17, no. 1 (1983): p.78.

${ }^{88}$ Douglas McCalla. Consumers in the Bush. p.48.

${ }^{89}$ Douglas McCalla. Consumers in the Bush. p.37.
} 
Like Freel and his family, Gonder was certainly making and mending his own clothes and possibly even making his own shoes. In Gonder's scrapbook on the 23rd February 1807, is a note from another Chippewa proprietor James Macklem: “Received from M Jacob Gonder Six pairs of Mens "Coanc"? Shoes which I will sell for him at two Dollars per pair or Return on Demand. 23rd February 1807, James Macklem" (Figure 1.4.) ${ }^{90}$ Elsewhere, Gonder’s account books show purchases of "uppers for shoes", and yards of "pattened"? leather, which leads to the assumption that he was making them, rather than having obtained the shoes from elsewhere through trade or at another store. In Niagara in the early nineteenth century then, home commercial production existed, with homesteads making goods at home to sell locally. This was the nature of local wool production as well, with wool carding done at local mills, weaving and spinning completed for hire, and the cloth and knitting products sold at local stores. ${ }^{91}$ The feasibility of Gonder's home shoe production is corroborated by frequency of Britain's leather export to North America (Table 1.2). British leather product was certainly available in Upper Canada, with 42\% of all British leather manufacture going to North America between 1763 and 1778, and $8 \%$ between 1797 and 1805 . The $42 \%$ spike is likely in no small part due to the American Revolutionary War and the demand for shoes and leather goods for British militia. Military needs greatly impacted consumption patterns and directly interfered with the consumption of materials by non-military citizens. ${ }^{92}$

On January $26^{\text {th }}, 1806$, George Ridout wrote to his parents in York, Upper Canada. His father, Thomas Ridout, was the Surveyor General in John Graves Simcoe's administration. ${ }^{93}$

\footnotetext{
${ }^{90}$ James Macklem to Jacob Gonder, 23rd February 1807. Gonder Family Fonds, 1796-1850. Archives of Ontario, F 1138-8, reel MS 193/17.

${ }^{91}$ Douglas McCalla. Consumers in the Bush. p.38-39.

${ }^{92}$ Giorgio Riello. A Foot in the Past: pp.45-46

${ }^{93}$ Burns, Robert J. "Ridout, Thomas" 1987. Dictionary of Canadian Biography. http://www.biographi.ca/en/bio/ridout_thomas_6E.html (Accessed March 3 2018).
} 
He writes: "Tom's shoes as well as my own are most worn out. Mr. Strachan hold Tom to get a pair of boots but we would like to know whether we shall get boots or shoes. I think that shoes will do as boots will come a dollar dearer than shoes and not as much better." ${ }^{94}$ Table 3 shows a gradual and substantial increase of the amount of shoes being exported from Britain over the eighteenth century, reaching 500,000 pairs of shoes by the year 1800 . Shoes were therefore both the cheaper option and likely more readily available. Although, the fact that boots came "a dollar dearer" could also have something to do with them being highly fashionable at the time of George's writing in 1806. Along with carrying associations of country living and outdoor life, boots and military values were closely associated together in late-eighteenth early nineteenth century Britain. ${ }^{95}$ Beginning with the popularity of the Hessian boot in $1789,{ }^{96}$ the Napoleonic wars and subsequently the war of 1812 had a major influence on masculine fashionable footwear. In his study A Foot in the Past, Giorgio Riello states: "At the end of the eighteenth century boots were used on all occasions, symbolizing a modern sense of mobility and participation in public life. Bootmaking experienced a period of unique growth and was considered at least until the early 1820 s the highest point of the shoemaking trade. ${ }^{.97}$ British shoe and leather exports to Upper Canada and Jacob Gonder's home shoe production allowed rural communities to participate in the footwear industry of the day, albeit in a North American context.

\footnotetext{
${ }^{94}$ George Ridout to Parents, York, Upper Canada 27th January 1806. F 43 Thomas Ridout Family Fonds, Archives of Ontario, Reel MS 537 (1).

${ }^{95}$ Giorgio Riello. A Foot in the Past. pp.70-71.

${ }^{96}$ Hessian boot $\mathrm{n}$. a kind of high boot, with tassels in front at the top, first worn by the Hessian troops, and fashionable early in the 19th century. "Hessian, adj. and n.1". OED Online. January 2018. Oxford University Press. http://www.oed.com.ezproxy.lib.ryerson.ca/view/Entry/86395?redirectedFrom=hessian+boot (accessed February 27, 2018).

${ }^{97}$ Giorgio Riello. A Foot in the Past. pp.72-73.
} 
Contrary to the 'homespun' narrative of Upper Canadian textile literature, rural store records from the early nineteenth century indicate a substantial number of ready-made and fabric purchases from Britain occurring in very rural areas. As McCalla maintains, representing rural settlers as "isolated from the currents of the global economy would entirely misrepresent their experience... [settlement] would have been impossible if settlers actually had to live outside the markets through which those currents flowed." ${ }^{98}$ Far from being a commodity-scarce wilderness, Upper Canada's dependence on the British economy for many everyday goods was both "substantial and not problematically costly." ${ }^{\prime 99}$ Goods were surprisingly accessible, as Upper Canada was a participant in the greater global consumer revolution, with imports making their way into even modest rural dwellings. ${ }^{100}$ This is not to say that goods were not produced locally or that there was not a household economy. The story of consumption in early Upper Canada is a balance of a rural household economy with the influx of material goods helping to improve the efficiency of local production. Jacob Gonder purchased darning needles to mend his garments, as well as textiles and goods to produce goods he was selling at market. That a substantial amount of families' incomes were spent on clothing and clothing items is an indication of the position of clothing in the forefront of rural lives in Upper Canada. Clothing was valued and also valuable, with ready-made items being the most costly of the Freels' purchases in 1808-1809. By incorporating data from rural areas that provide the details of what people were buying, and consequently making and doing, we begin to form a clearer picture of early Upper Canadian

\footnotetext{
${ }^{98}$ Douglas McCalla. Consumers in the Bush: Shopping in Rural Upper Canada. p.9.

${ }^{99}$ Ibid. p.152.

100 T.H Breen. The Marketplace of Revolution: How Consumer Politics Shaped American Independence. New York: Oxford University Press, 2004. P. xvii. As quoted in Douglas McCalla. Consumers in the Bush: Shopping in Rural Upper Canada. P.12.
} 
consumption and material life. We can count Upper Canada as participating in the global consumption patterns of the late eighteenth and early nineteenth centuries. 


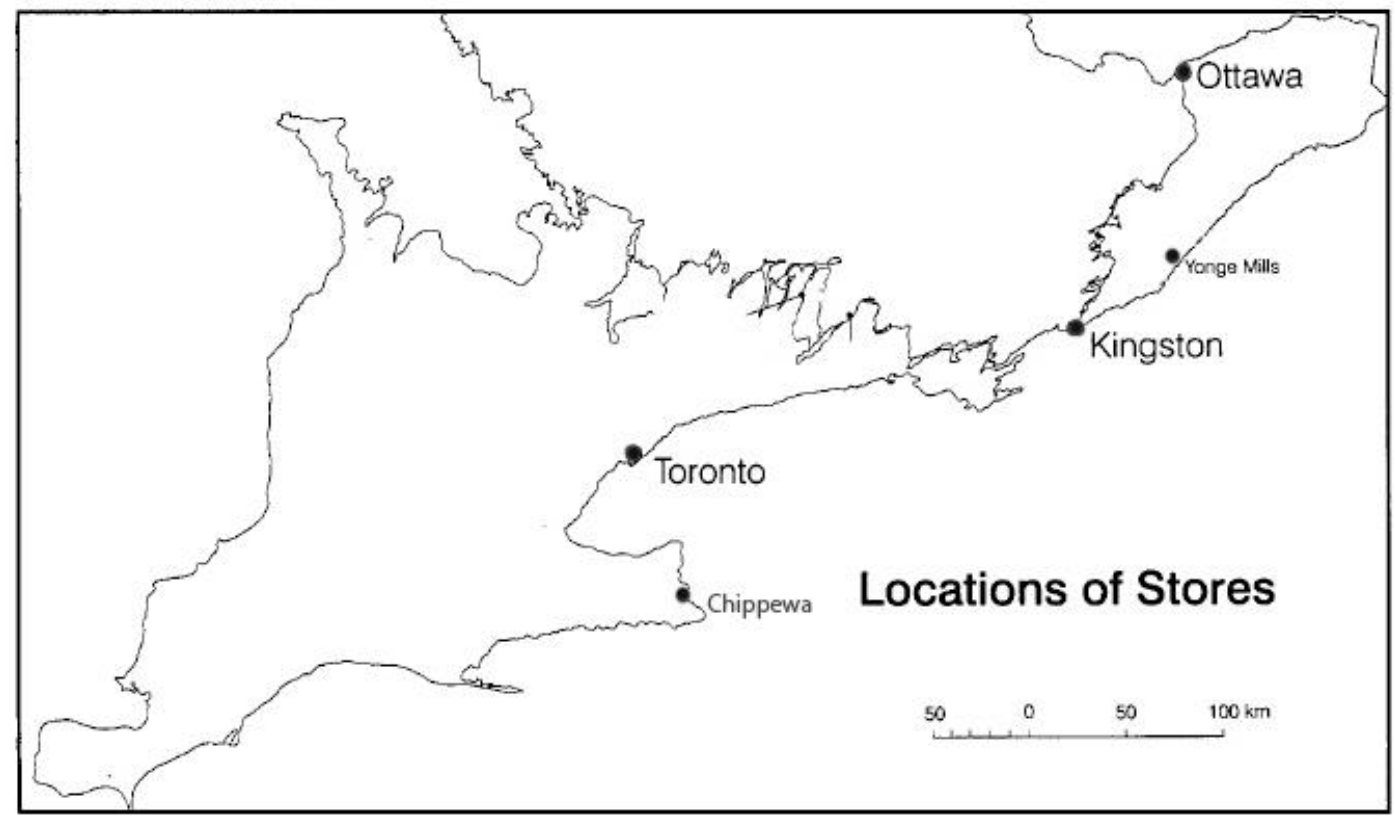

Figure 1.1. Locations of Mentioned General Stores and Urban Centres in Upper Canada, 18081817. Source: McCalla, Douglas. "Textile Purchases by Sorte Ordinary Upper Canadians, 18081861." Material Culture Review / Revue de la culture matérielle [Online], 53.1 (2001).

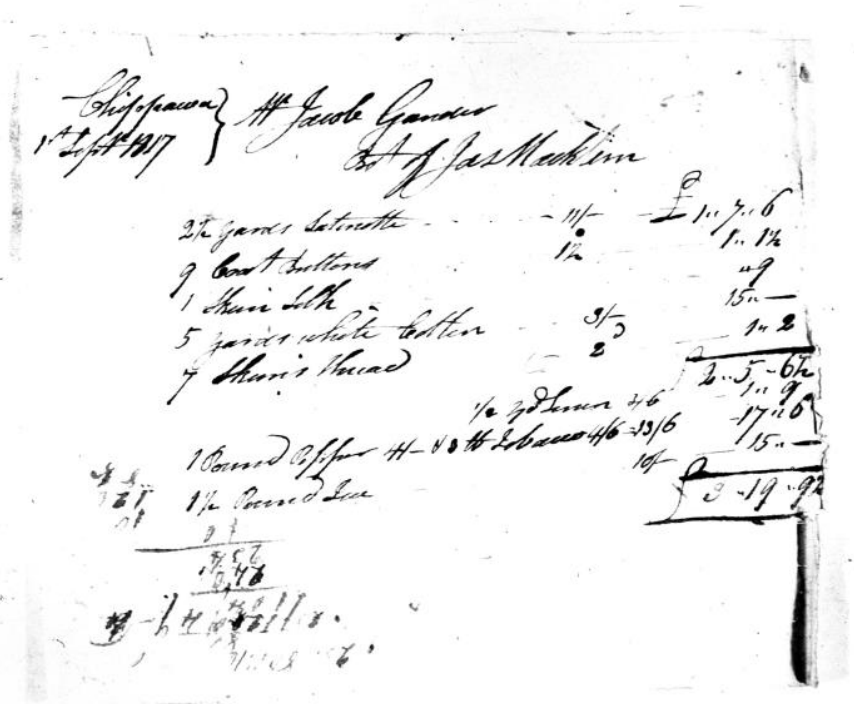

Figure 1.2. Gonder purchases of Coat Buttons, Silk and Thread, 1817. Gonder Family Fonds, 1796-1850. Archives of Ontario, F 1138-8, reel MS 193/17. 


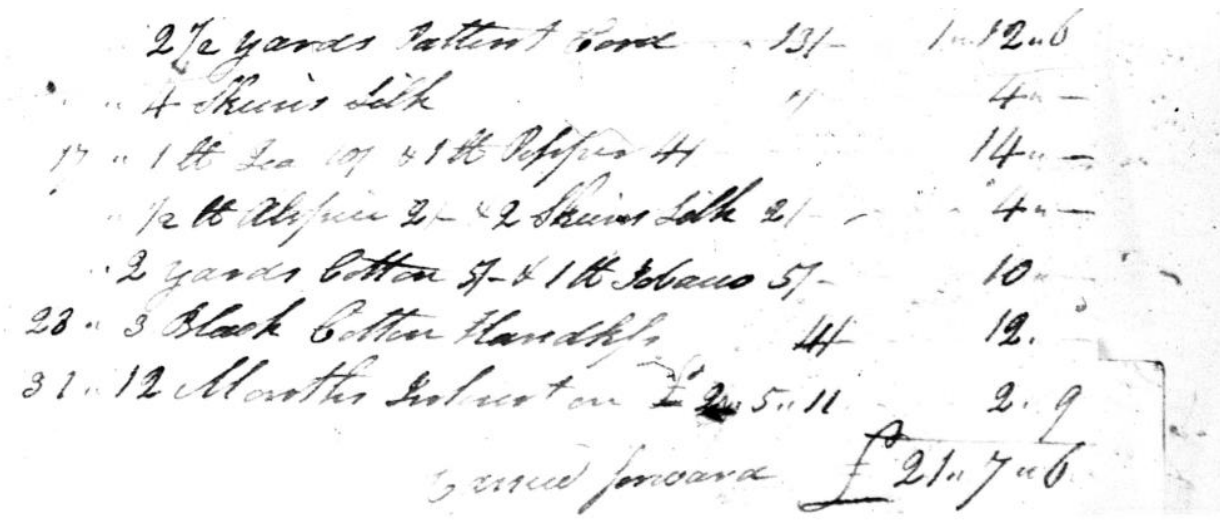

Figure 1.3. "3 Black Cotton Handkerchiefs," 1816. Gonder Family Fonds, 1796-1850. Archives of Ontario, F 1138-8, reel MS 193/17.

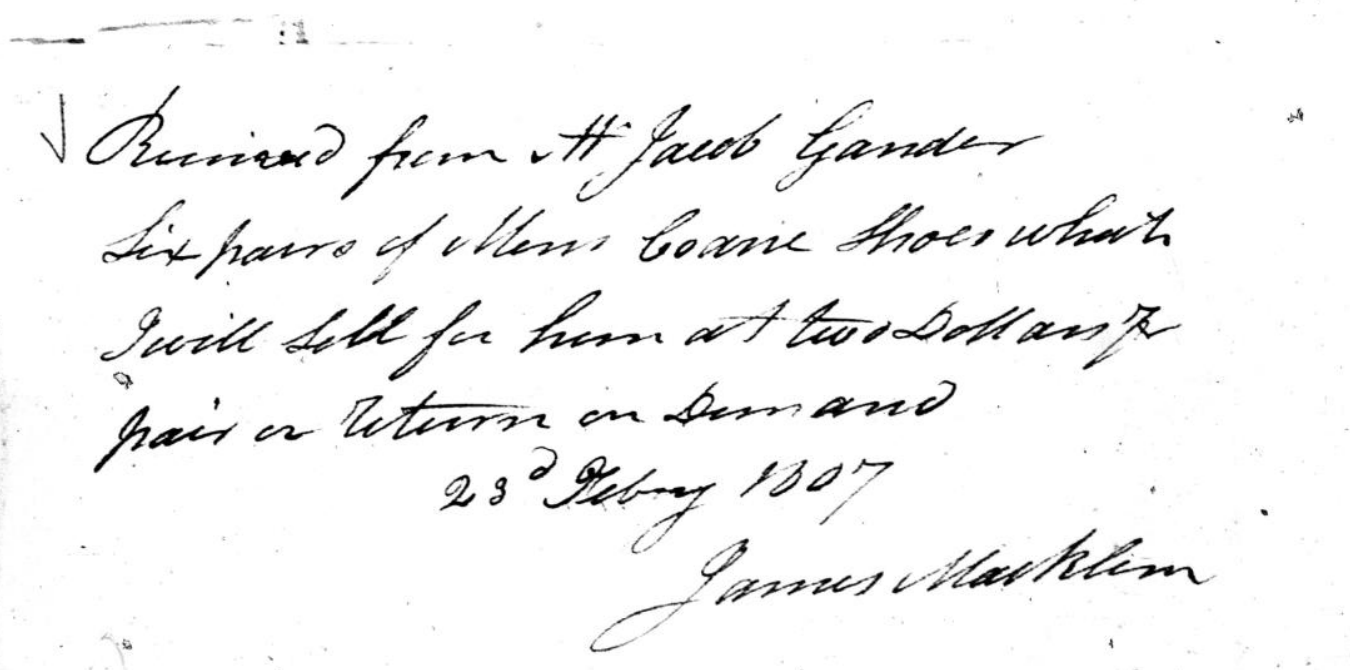

Fig 1.4. James Macklem to Jacob Gonder, 23rd February 1807. Gonder Family Fonds, 17961850. Archives of Ontario, F 1138-8, reel MS 193/17. 
Table 1.1 Thomas Freel's Textile and Related purchases, September 1808 to May 1809

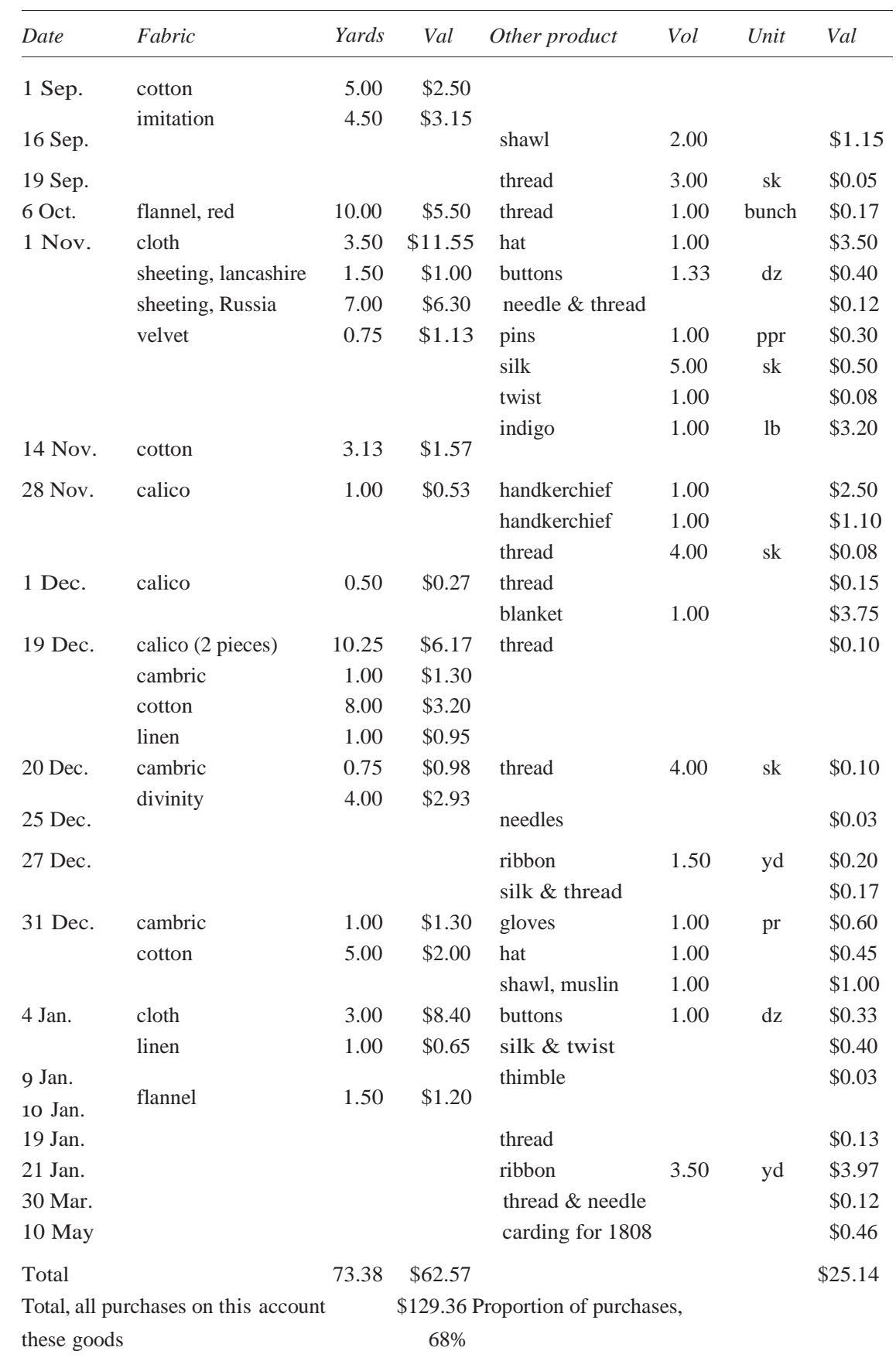

Source: Douglas McCalla. Consumers in the Bush: Shopping in Rural Upper Canada. vol. 3;3, McGill-Queen's University Press, 2015. Appendices p.164. 
Table 1.2. Export of British Leather Manufacture, 1763-1778 and 1797-1805 (\%)

\begin{tabular}{|l|l|l|}
\hline Area & $1763-1778$ & $1797-1805$ \\
\hline Continental Europe & 17 & 10 \\
East Indies & 11 & 6 \\
West Indies & 30 & 74 \\
North America & 42 & 8 \\
Rest of the World & 0 & 2 \\
Total & 100 & 100 \\
\hline
\end{tabular}

Source: John Ramsay McCulloh, A Dictionary, Practical, Theoretical and Historical of Commerce and Commercial Navigation. (London 1834) pp. 345-6; As reproduced in Giorgio Riello. A Foot in the Past: Consumers, Producers and Footwear in the Long Eighteenth Century. Vol. 15. Oxford: Oxford University Press, 2006. P.50.

Table 1.3. Estimated English Shoe Export 1700-1800 (five year moving average)

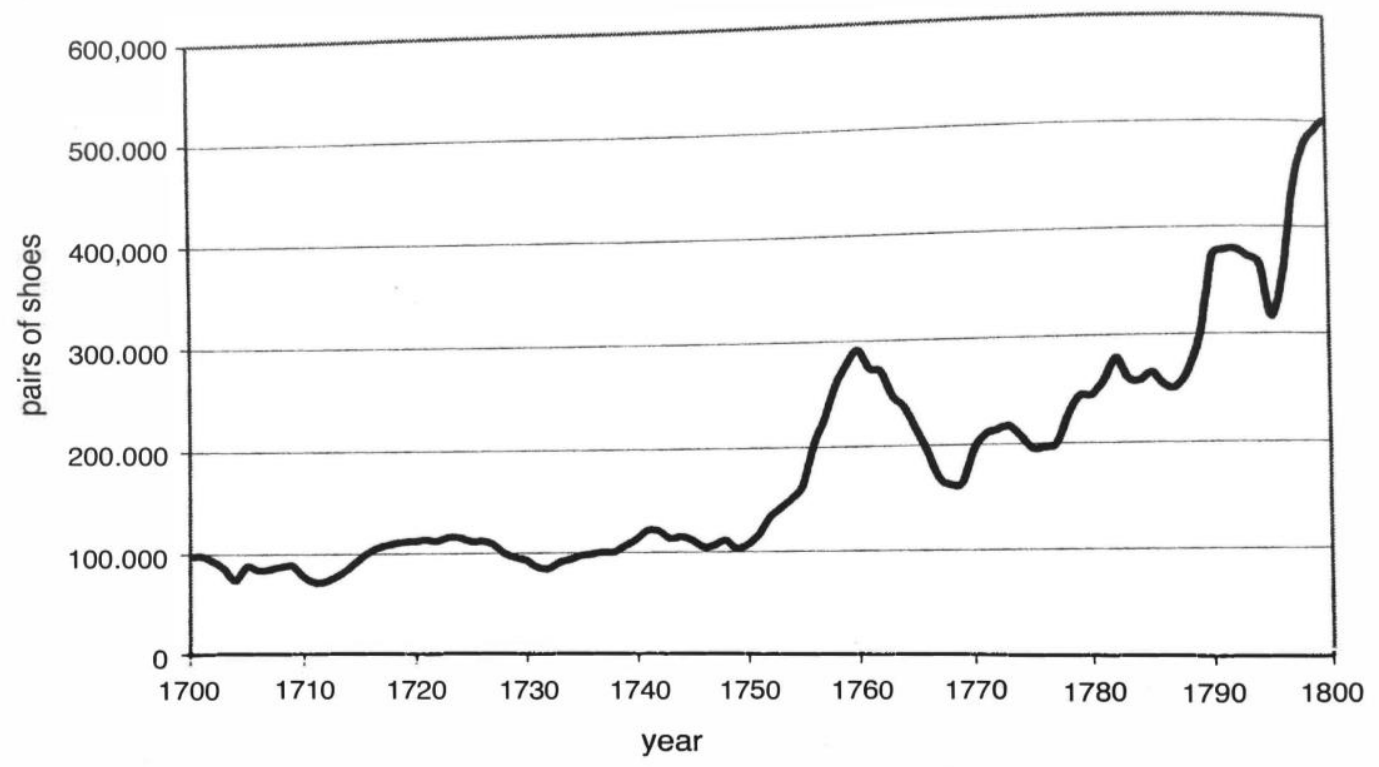

Source: Elizabeth B. Schumpeter, English Overseas Trade Statistics, 1697-1808 (Oxford, 1960), 32-3; Joseph Massic, Considerations on the Leather Trades of Great Britain (London 1757), 1822. As reproduced in Giorgio Riello. A Foot in the Past: Consumers, Producers and Footwear in the Long Eighteenth Century. Vol. 15. Oxford: Oxford University Press, 2006. p.50. 


\section{Chapter 2}

Loyalty: Simcoe's Rangers and Dress in Upper Canada, 1791-1796

John Graves Simcoe, appointed the first lieutenant-governor of the Province of Upper

Canada, arrived with his wife Elizabeth Posthuma Simcoe to North America in 1791 and stayed until 1796. Simcoe had previously served as Commander of the Queen's Rangers, a British militia unit fighting on the Loyalist side during the American Revolutionary War. ${ }^{101}$

Correspondence between the British Secretary-at-War to Army Secretary Thomas Fauquier on the $7^{\text {th }}$ of October 1791 confirmed the new assignment of Simcoe's regiment in Upper Canada:

His Majesty having been pleased to order that a Corps of Foot for service in the Province of Upper Canada, under the command of Colonel John Graves Simcoe...The uniform of the said Corps shall be green, and of the same pattern as was worn by the late Corps of Queens Rangers, which Colonel Simcoe commanded during the last war. ${ }^{102}$

In addition, the uniform had "a blue cuff, and collar, bordered with white lace." ${ }^{103}$ A surviving Queen's Rangers uniform jacket is on display at the Fort York Museum in Toronto (Fig.2.). It belonged to Captain William Jarvis, who became the Provincial Secretary of Upper Canada. ${ }^{104}$ The jacket has silver gilt buttons, silver cord epaulettes and originally cost $£ 1 / 1 / 11 .{ }^{105}$ The green jacket is distinct from the scarlet coats of other British regiments, a conscious decision made by John Graves Simcoe creating a sense of pride in his unit. The Queen's Rangers new assignment in Upper Canada was in a time of peace, and according to James Laver's analyses of the

\footnotetext{
${ }^{101}$ David Mills. The Idea of Loyalty in Upper Canada, 1784-1850. (Kingston and Montreal: McGill-Queen's University Press) 1988. P.17.

$1027^{\text {th }}$ October 1791. Letter Book of the Board of General Officers on Clothing. Secretary-at-War to Thomas Fauquier, Esqre. W.O. 7/29, p.72. As reproduced in Hew Strachan. British Military Uniforms, 1768-1796. The Dress of the British Army from Official Sources. London: Arms and Armour Press, 1975. p.263. $10318^{\text {th }}$ November 1791. Commander-in-Chief out letter. Adjutant-General to Thomas Fauquier Esqre. W.O. 3/10, p.81. As quoted in Hew Strachan, British Military Uniforms, 1768-1796. The Dress of the British Army from Official Sources. London: Arms and Armour Press, 1975 p. 263.

${ }^{104}$ William Jarvis Uniform, An Officer in the Queen's Rangers, 1791. City of Toronto Museum Collections, Fort York, Toronto. From: Fort York Gallery, https://www.fortyork.ca/29-gallery (accessed February 13, 2018). 105 Ibid.
} 
functions of military dress, uniforms in times of peace reinforce hierarchical structures by making rank plainly visible. ${ }^{106}$ Distinct from the greater symbolism of the entire British imperial system, Simcoe's green uniforms symbolized power unique to Simcoe's role as Lieutenant Governor of Upper Canada. Simcoe's Queen's Rangers were a major imperial presence in Newark and York from 1792-1796. In their green uniforms they carried out the construction of many new buildings and roads, ${ }^{107}$ and were present for governmental ceremonies, such as the opening of the legislature in $1795 .{ }^{108}$ The Queen's Rangers functioned as a reinforcement of imperial power and John Graves Simcoe's authority. In her introduction to her version of Elizabeth Simcoe's diaries published in 1965, Mary Quayle Innis writes John Simcoe "had fought during the American Revolution and was eager to bring to the wilds of Upper Canada the beneficent British institutions that the Americans had rejected." 109 This was the perspective of Simcoe and the appointed seat of government. Simcoe was sent to implement the intentions of the British imperial authorities.

Drawing from a long tradition of Canadian historiography, historian David Mills maintains the study of the idea of loyalty is fundamental to an understanding of the political culture of early Upper Canada. ${ }^{110}$ This chapter aims to explore the ideas that permeated within the ruling elite, how they shaped the political culture of Upper Canada, and the role dress played in reinforcing those ideas. Though the physical presence and symbolism of imperial uniforms, the conventions of European portraiture, and rigorous efforts to maintain the cultural practices of

\footnotetext{
106 James Laver. Modesty in Dress: An Inquiry into the Fundamentals of Fashion, Boston: Houghton Mifflin 1969. p. 63.

${ }^{107}$ Mary Beacock Fryer and Christopher Dracott. John Graves Simcoe, 1752-1806: A Biography. p.158.

${ }^{108}$ Mary Quayle Innis. Mrs. Simcoe's Diary. Toronto: Dundurn Press, 2007. p.26.

${ }^{109}$ Ibid. p. 16.

${ }^{110}$ David Mills. The Idea of Loyalty in Upper Canada, 1784-1850. p.3.
} 
the parent nation, dress aided to visually establish and maintain power in Upper Canada's very

early and insular British colonial society. The central idea that shaped this society was loyalty. ${ }^{111}$ Loyalty

David Mill's publication The Idea of Loyalty in Upper Canada 1784-1850 identifies loyalty as the most important belief in Upper Canada's early political discourse. ${ }^{112}$ Simcoe and his administration brought with them a very specific notion of loyalty, heavily rooted in the late eighteenth-century Tory tradition in England. ${ }^{113}$ Simcoe "envisioned the development within an imperial structure of a provincial society loyal to the Crown and deeply committed to fundamental British values and institutions." 114 This stance is reflected in the Constitutional Act of 1791, which acted as an extension of the British constitution and governing principles into the new colonies. ${ }^{115}$ Loyalty meant intense allegiance to these governing principles and fervent commitment to establishing British institutions on colonial soil. Simcoe's oligarchy held such a conservative outlook that any dissention was equated with disloyalty, and to be crushed immediately. ${ }^{116}$ The strength of this mentality inflicted a great measure of "ideological conformity" 117 within the Simcoe administration and the administrations thereafter, lasting up until $1820 .^{118}$

Further evidence of efforts to transplant the Tory tradition to Upper Canada is written into the Constitutional Act of 1791. Part of the act aimed to establish a landed aristocracy in Canada, giving them the right to be summoned to the legislative council. An aristocracy was

\footnotetext{
${ }^{111}$ David Mills. The Idea of Loyalty in Upper Canada, 1784-1850. p.3.

112 Ibid. p.3.

113 Ibid. p.12.

114 Ibid. p.12.

115 The Editors of Encyclopaedia Britannica. "Constitutional Act" Encyclopaedia Britannica. Encyclopaedia Britannica, inc. 25 July 2013. https://www.britannica.com/event/Constitutional-Act (Accessed February 15, 2018).

${ }^{116}$ David Mills. The Idea of Loyalty in Upper Canada, 1784-1850. p.12.

117 Ibid. p.12.

${ }^{118}$ Ibid. p.12.
} 
never established. ${ }^{119}$ Deliberate attempts to build an aristocracy and maintain British sovereignty in Upper Canada reveal fear of republican principles that flourished in America and resulted in the American War of Independence. Waves of American migrants who settled in Upper Canada also posed a threat, in case they absorbed any republican ideas. ${ }^{120}$ Upper Canada was to be the staunch stronghold of the British Crown, and no disloyalty could be tolerated.

\section{Queen's Rangers}

In addition to Tory attitudes, Simcoe also brought residual Loyalist attitudes from his role as commander of the Queen's Rangers during the American Revolution. The Queen's Rangers, known informally as Simcoe's Rangers, had gained the reputation of being one of the most effective regiments that fought on the British side of the American Revolution. ${ }^{121}$ Their attitudes towards American rebels are captured in a song written by Captain Smyth of the Queen's Rangers in 1778. ${ }^{122}$ The central theme is the "hunting-shirts and rifle-guns," of the American rebels, reflecting their dishonourable state:

Forgetting the mercies of Great Britain's king, Who saved their forefathers' necks from the string; With their hunting-shirts, and rifle-guns. They renounce allegiance and take up their arms, Assemble together like hornets in swarms, So dirty their backs, and so wretched their show, That carrion-crow follows wherever they go, With their hunting-shirts, and rifle-guns. ${ }^{123}$

For the Queen's Rangers, the dress of the American rebels is reason enough for contempt. But more than this, their dishonour and lawlessness lead them to curse the rebels to be "fed with hot

\footnotetext{
119 The Editors of Encyclopaedia Britannica. "Constitutional Act” Encyclopaedia Britannica.

${ }^{120}$ David Mills. The Idea of Loyalty in Upper Canada, 1784-1850. p.5.

${ }^{121}$ Mary Beacock Fryer and Christopher Dracott. John Graves Simcoe, 1752-1806: A Biography. Dundurn Press, 1998. p.33-34.

122 “The Rebels, 1778” American Revolution.Org. Last Modified 2017. http://www.americanrevolution.org/war_songs/warsongs51.php (Accessed February 13, 2018).

123 "The Rebels, 1778" American Revolution.Org.
} 
sulphur from Lucifer's kitchens." 124 The hunting-shirts of the rebels (Figure 2.1) were tan in colour with matching trousers, and decorated with a fringe. ${ }^{125}$ They were essentially a farmer's or laborer's smocks with embellishments, and distinctly a North American garment. ${ }^{126}$ Thomas S. Abler, author of Hinterland Warriors and Military Dress, calls the hunting shirt a frontier garment inspired by American native dress, however "the degree to which it owes any ancestry to native North Americans is questionable." 127 The garment was issued to all of the Continental Army by General George Washington during the American Revolution, and continued to be the summer dress of the US Rifle Regiment throughout the War of $1812 .{ }^{128}$ Unlike the Queen's Rangers dressed in green regimentals (Figure 2.2), the American Continental hunting shirt represented the antithesis of Loyalist values. It was essentially a farmer's or labourer's smock, setting the American Continental Army apart from the smart, polished imperial uniforms of the Queen's Rangers and other British regiments. ${ }^{129}$ Dress functioned as a symbolic mark of differentiation, the difference between honour and dishonour, loyalty and disloyalty.

\section{Functions of Military Dress}

The pioneering fashion historian James Laver from the Victoria and Albert Museum identified six functions for military dress in his 1969 work Modesty in Dress: An Inquiry into the Fundamentals of Fashion. They are increasing sense of individual pride, decreasing enemy morale, recognition on the battlefield, increasing unit esprit de corps, clear rank distinction, and

\footnotetext{
124 “The Rebels, 1778” American Revolution.Org.

125 Ibid.

${ }^{126}$ Thomas S. Abler Hinterland Warriors and Military Dress: European Empires and Exotic Uniforms. Berg, 1999. p. 138.

${ }^{127}$ Ibid. p.138.

${ }^{128}$ Ibid. p.138.

${ }^{129}$ Ibid. p.138.
} 
protection for the wearer. ${ }^{130}$ Along with these six practical functions, Laver established underlying principles of military dress. Particularly in the uniforms of the late-eighteenth century, the most significant of these is the seduction principle: "A smart uniform enhances a man's masculinity... It gives him a head-dress which exaggerates his height; it puts a stripe on his trousers to exaggerate his apparent length of leg; it gives him epaulettes to exaggerate the width of his shoulders. It is the very epitome of the Pride of Life." ${ }^{\prime 31}$ Uniforms operating under Laver's seduction principle tend to restrict movement and practicality on the battlefield, ${ }^{132}$ thus the effectiveness of the seduction principle is best during times of peace. The Queen's Rangers uniforms functioned under both hierarchical and seduction principles in their assignment in Upper Canada. The transformation of civilian male dress at the end of the eighteenth century consisting of "the adoption of a tightened and smartened version of country clothes" 133 became reflected in military uniforms, and emphasis was placed on a masculine and smart appearance.

The emphasis on a smart appearance and strict regulations concerning every aspect of dress in the British Army during the eighteenth century is represented in Bennett Cuthbertson's 1768 volume A System for the Compleat Interior Management and Oeconomy of a Battalion of Infantry. ${ }^{134}$ An officer himself, Cuthbertson's book was highly influential and concerned every aspect of regimental administration. There was also a 1776 edition, ${ }^{135}$ a timely release for guidance during the American Revolutionary War. (1775 - 1783). Cuthbertson's section on the clothing of a regiment is extensive, with over fifty articles detailing the correct way to cock a

\footnotetext{
${ }^{130}$ James Laver. Modesty in Dress: An Inquiry into the Fundamentals of Fashion, Boston: Houghton Mifflin 1969. p. 63. As quoted in Thomas S. Abler Hinterland Warriors and Military Dress. p. 15.

${ }^{131}$ James Laver. Modesty in Dress. p.72-73

132 Thomas S. Abler Hinterland Warriors and Military Dress. p. 14.

133 James Laver. Modesty in Dress. p.68

${ }^{134}$ Bennett Cuthbertson, A System for the Compleat Interior Management and Oeconomy of a Battalion of Infantry. (Dublin, 1768, Bristol 1776). As reprinted in Hew Strachan, British Military Uniforms, 1768-1796. The Dress of the British Army from Official Sources. London: Arms and Armour Press, 1975. pp. 137-168.

${ }^{135}$ Hew Strachan, British Military Uniforms, 1768-1796. p. 137.
} 
soldier's hat, to the appropriate amount of shirt cuff exposed under the coat, to how to recycle worn coats into caps. ${ }^{136}$ The exactness of a soldier's uniform was of extreme importance, with emphasis on smartness, cleanliness and uniformity. For stockings, as an example:

The greatest uniformity should be observed, in the colour of the stockings, through a Regiment, as nothing more offends the eye, than a variety in this particular: white, besides being the most showy, is the readiest colour to be obtained in all places; nor will they be found so difficult to keep clean... ${ }^{137}$

The strict and highly regimented nature of British military dress is a reminder of imperial power on colonial soil. Under Laver's hierarchical principle during times of peace the smartness of a uniform served as a representation of the power of the British Empire.

The green jackets of the Queen's Rangers were distinct from the red jackets of the British regulars. This was initially to distinguish Provincial Corps in America from British Corps in Britain. ${ }^{138}$ When the Provincial Corps had proved their value, they were 'upgraded' and made to wear the famous redcoats. John Graves Simcoe resisted this change however, and kept the Queen's Rangers in green. The choice to keep the green uniforms was for a few reasons: one being green is a better camouflage among the foliage, and some American rebel regiments wore green as well. Sharing uniform colours with enemy regiments allowed Simcoe and his rangers to maneuver around the enemy without being identified immediately as a British regiment. ${ }^{139}$ Another reason for this colour choice was to keep the Queen's Rangers distinct from other British regiments. In his work Uniforms and Nonuniforms: Communication through Clothing, Nathan Joseph identifies a pattern throughout the evolution of military dress in which elite units

\footnotetext{
${ }^{136}$ Bennett Cuthbertson, A System for the Compleat Interior Management and Oeconomy of a Battalion of Infantry. (Dublin, 1768, Bristol 1776). As reprinted in Hew Strachan, British Military Uniforms, 1768-1796., pp. 137-168.

${ }^{137}$ Bennett Cuthbertson, A System for the Compleat Interior Management and Oeconomy of a Battalion of Infantry. As quoted in Hew Strachan, British Military Uniforms, 1768-1796. p. 146.

${ }^{138}$ Mary Beacock Fryer and Christopher Dracott. John Graves Simcoe, 1752-1806: A Biography. p.34.

${ }^{139}$ Ibid. p.34.
} 
purposely distinguish their dress from other regiments, inspiring pride in their units. ${ }^{140}$ The distinction in dress becomes "a proud symbol of [the] elite fighting corps."141 The visual marker of a green uniform became a symbol of the Rangers success during the American Revolution, and their elite status as a special regiment. Simcoe's decision to carry over the war-time symbolism to Upper Canada in a time of peace was certainly a reference to his military successes during the American Revolution and his authority.

Understanding Simcoe's political disposition can provide indications of the symbolic nature of dress being used to administer conservative values. His portrait (Figure 2.3) painted in 1791 by Jean-Laurent Mosnier, former painter to the French court, employs the conventions of eighteenth-century portraiture. A tricky "fusion of character, likeness and costume,"142 Simcoe wears the Queen's Rangers green jacket, posed to the right so as to feature the brilliant silver cord epaulettes. Simcoe wears a very conspicuous gentleman's shirt under the jacket, displaying his social rank in tandem with his military one. Aileen Ribeiro's 1995 study The Art of Dress breaks down how male social ambition and prowess was often portrayed in eighteenth-century portraiture:

Men... could be painted at various stages in their lives and careers; active in the world of affairs, their portraits showed them in Protean guise, as warriors, statesmen, professionals, as well as in the costume of rank and status. As Goethe noted: "A man's fairest memorial is...his own portrait... It is the best text to the music of his life."143

Simcoe's portrait was painted in 1791, the year he was made Lieutenant Governor of Upper Canada. Ribeiro asserts that the choice of dress is of vital importance in portraiture, because it is

\footnotetext{
${ }^{140}$ Nathan Joseph. Uniforms and Nonuniforms: Communication through Clothing. New York: Greenwood 1986. P. 77. As quoted in Thomas S. Abler Hinterland Warriors and Military Dress: European Empires and Exotic Uniforms. Berg, 1999. P. 15.

${ }^{141}$ Ibid. p. 77 \& p. 15.

142 Aileen Ribiero. The Art of Dress: Fashion in England and France, 1750-1820. New Haven: Yale University Press, 1995 p.6.

${ }^{143}$ Ibid. p.1750-1820. p.7
} 
through the dress of the sitter that a precise moment in time will be expressed, along with a complex combination of the ideas of the sitter and the artist. ${ }^{144}$ Simcoe is portraying his role as Commander of the Queen's Rangers, recalling the regiments exploits and loyalty to the Crown during the American Revolution. The Epaulettes mirror the sheen of Simcoe's shirt, drawing the eye to both elements simultaneously. Simcoe is at once a military commander and a gentleman. Likely chosen by the artist Jean-Laurent Mosnier, Simcoe's pose allows for the display of the decorative elements of the jacket. We can see that the collar of the jacket is worn from use. Simcoe is a seasoned veteran and humble servant to the King. Painted in London before his departure for North America, this portrait provides an indication of the nature of the leadership role Simcoe was to take. He was to become a Governor who embodied the conservative principles of British politics, mixed with emotionally charged Loyalist sentiment from the Revolutionary War. In this context, Simcoe's clothing reveals his character, past, present and future.

\section{Simcoe's Government}

Writing from Newark, Attorney General John White described Governor Simcoe “(a most upright man) is wholly military, he cannot hear any thing like civil inquiry or proceeding." 145 Simcoe frequently butted heads with Lord Dorchester, the Governor General of British North America, whom the author of Canadian Letters described as apathetic. ${ }^{146}$ Surviving letters describe the pomp and circumstance of the opening of the legislature in 1795: "The whole retinue of the Governor consisted in a guard of fifty men of the garrison of the fort. Dressed in silk, he entered the Hall with his hat on his head, attended by the Adjutant and 2

\footnotetext{
${ }^{144}$ Aileen Ribiero. The Art of Dress. p.6.

${ }^{145}$ Shepherd-White Papers, Public Archives of Canada. As quoted in Mary Quayle Innis. Mrs. Simcoe's Diary. p.31.

${ }^{146}$ Mary Quayle Innis. Mrs. Simcoe's Diary. p.31
} 
Secretaries." ${ }^{147}$ The description mentions the contrast of the red coats of the garrison lined up beside the dark green coats and white pipeclayed ${ }^{148}$ breeches, as well as the powdered hair tied back below their helmets. ${ }^{149}$ Salutes were fired from Fort Niagara, and bands played music. ${ }^{150}$ This ceremony marking the opening of the lawmaking session also functioned as a reinforcement of the Sovereignty of the Crown. An interesting note is the mention of Simcoe's silk shirt and hat during the ceremony. Simcoe's deliberate use of expensive and rare materials can be read as a symbol of his authority.

Beyond political ceremony, imperial authority was extended into attempts to recreate a British aristocratic society in Newark. Despite the underdeveloped and uncomfortable conditions of the make-shift buildings and facilities, every effort was made to continue the upper class lifestyle the British officials were accustomed to. Balls were given in Newark where the "standard of dress and deportment were just as high" as in Britain. ${ }^{151}$ The author of Canadian Letters, wrote "Can I be at the extremity of Lake Ontario? Many of them are very pretty women, and, after having figured at a ball, return home with renewed cheerfulness to the performance of their household duties, which are peculiarly necessary in a colonial life." ${ }^{152}$ Letters written by Mrs. Jarvis, wife of William Jarvis the Provincial Secretary, poke fun at the ornaments piled high on some of the women's caps, while Mrs. Macaulay, the wife of the surgeon to the Queen's Rangers, praised the presence of gauze dresses, wax candles, supper and tea at a ball in $1792 .{ }^{153}$

\footnotetext{
${ }^{147}$ Francois de La Rochefoucauld-Liancourt. Travels Through the United States of North America...1795, 1796 and 1797 (2 Vols. London 1799), Vol. I 256 as quoted in Mary Quayle Innis. Mrs. Simcoe's Diary. p. 31.

${ }^{148}$ A fine white clay which forms a ductile paste with water, used esp. for making tobacco pipes, and also for whitening leather, polishing, etc. "pipeclay, n.". OED Online. January 2018. Oxford University Press. http://www.oed.com.ezproxy.lib.ryerson.ca/view/Entry/144386?rskey=nDc1zR\&result=2\&isAdvanced=false (accessed February 17, 2018).

${ }^{149}$ Mary Quayle Innis. Mrs. Simcoe's Diary. p.26.

${ }^{150}$ Ibid. p. 26

${ }^{151}$ Mary Quayle Innis. Mrs. Simcoe's Diary. p.26.

${ }^{152}$ Canadian Letters, p. 45. As quoted in Mary Quayle Innis. Mrs. Simcoe's Diary. p.26.

${ }^{153}$ Mary Quayle Innis. Mrs. Simcoe's Diary. p.26.
} 
It was important then to establish a society that was faithful to elite customs in the parent nation. Newark families wrote to loved ones in England asking for goods from home that were all scarce. Mrs. Jarvis often wrote asking for shoes for herself and her children and for "dark strong printed calico not too fine, narrow striped red and white cotton for the little girls' gowns - there was none in Newark or even Montreal under six shillings a yard." ${ }^{154}$ With the goal of establishing a transplanted British society, clothing played a vital role as a visual marker of British authority in both the political and societal spheres.

\section{Conclusion}

The Tory and Loyalist values held by Mr. and Mrs. Simcoe were expressed through dress in order to establish a Eurocentric society in its infancy. Historian J.M.S Careless maintains the Loyalists "represented a declaration of independence against the United States, a determination to live apart from that country in North America. As a result, they helped to create not only a new province, but a new nation." ${ }^{" 155}$ Perhaps it was not a creation of a new nation but strict adherence to the customs and principles of the old parent, Great Britain. Visual markers such as regimental uniforms, society balls and political pageantry were the manifestation of the conservative ideology the Simcoe administration upheld. These efforts would characterize the nature of politics and life in Upper Canada for decades to come.

\footnotetext{
${ }^{154}$ Mary Quayle Innis. Mrs. Simcoe's Diary. p.25.

${ }^{155}$ J.M.S Careless. Canada: A Story of Challenge. Toronto, 1953. p.113. As quoted in Norman J. Knowles Inventing the Loyalists. p.4.
} 


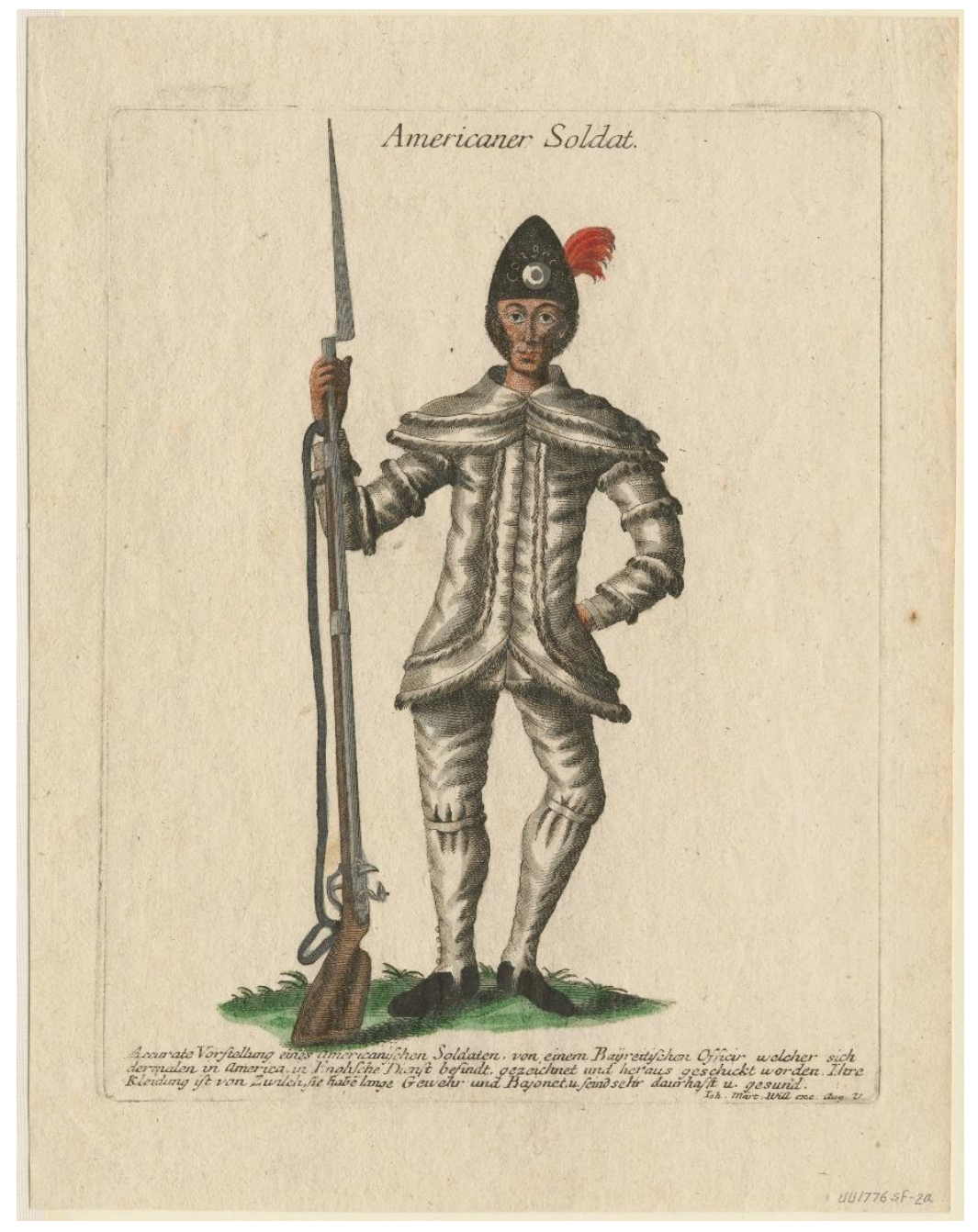

Fig. 2.1. Americaner Soldat, 1776. Supporter of the Continental Congress in a fringed hunting shirt. Published by Johann Martin of Augsburg. Brown University Library, Center for Digital Scholarship Digital Collections, Providence, Rhode Island. From: https://library.brown.edu/cds/catalog/catalog.php?verb=render\&id= (accessed February 21, 2018). Reproduced in Thomas S. Abler, Hinterland Warriors and Military Dress: European Empires and Exotic Uniforms. Berg, 1999. Plate 36. 


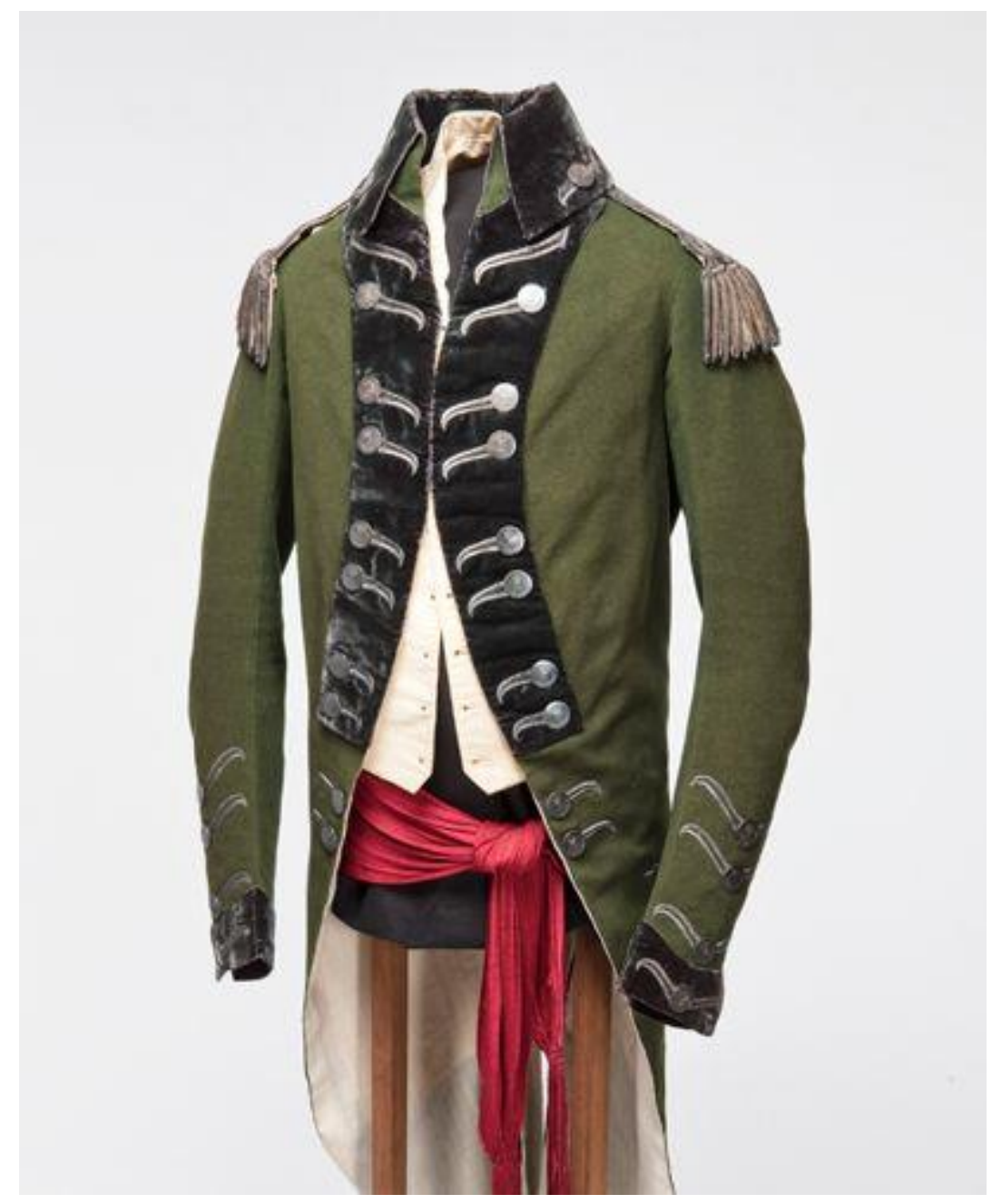

Fig. 2.2. William Jarvis Uniform, An Officer in the Queen's Rangers, 1791. City of Toronto Museum Collections, Fort York, Toronto. From: Fort York Gallery, https://www.fortyork.ca/29-gallery (accessed February 13, 2018). 


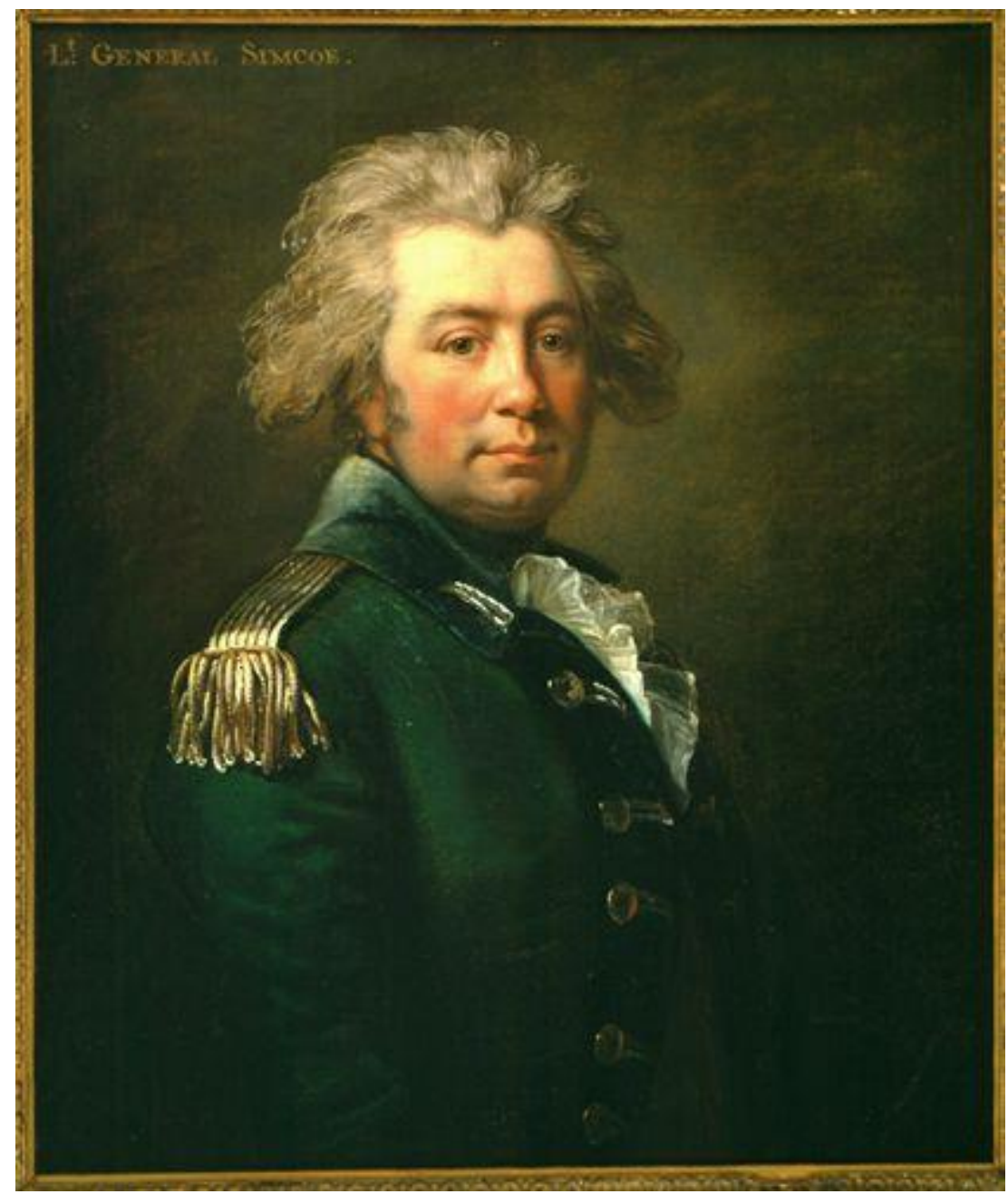

Fig. 2.3. Jean Laurent Mosnier (1743-1808) Portrait of Governor John Graves Simcoe. 1791. Toronto Public Library, Toronto. From: Fort York Gallery, https://www.fortyork.ca/29-gallery (accessed February 13, 2018). 


\section{Chapter 3}

Adaptability: Dress and Domesticity in Upper Canada, 1790-1840

Between 1790 and 1840 nearly half the population of Upper Canada was female. ${ }^{156}$ For working women, getting dressed in the morning was a systematic process. Upon waking up, a woman would already be wearing her linen shift, which served as both a night dress and the first layer next to the skin. Labouring class women usually had two shifts, for wearing while the other could be washed. ${ }^{157}$ She would then put on her knitted stockings, pulled above the knee and held in place by a garter. Shoes would be put on next, because once her stays were laced, it would be difficult to reach her feet. Shoes often had removable buckles. ${ }^{158}$ Stays for working women were less stiff than decorative stays of the upper classes and allowed for freedom of movement.

Leather stays were an inexpensive alternative to boned stays and more flexible (Figure 3.1). ${ }^{159}$

Once the stays were laced, multiple petticoats were put on, secured by long ties wrapped around the waist. Depending on the season, petticoats could be made of cotton or wool. Next, a neckerchief or a shawl was wrapped around the shoulders and tucked into the stays, followed by a jacket, with sleeve cropped at the elbows. For the head, a white linen cap was worn under a wide brimmed hat. Finally, an essential part of daily dress for the labouring woman was the apron, wrapped around her skirts with string. ${ }^{160}$ Working women often wore a garment called a short gown, or bed gown. (Figure 3.2). ${ }^{161}$ The main components are a straight-line cut, front

\footnotetext{
156 Jane Elizabeth Errington. Wives and Mothers, School Mistresses and Scullery Maids: Working Women in Upper Canada 1790-1840. Montreal: McGill-Queen's University Press, 1995. P. xi.

${ }^{157}$ Linda Baumgarten. What Clothes Reveal: The Language of Clothing in Colonial and Federal America. The Colonial Williamsburg Collection. New Haven: Yale University Press, 2002. P. 245

158 John Styles.The Dress of the People: Everyday Fashion in Eighteenth-Century England. London: Yale University Press, 2007. p.31.

159 Linda Baumgarten. What Clothes Reveal. p. 122

160 John Styles.The Dress of the People. p.31.

${ }^{161}$ Linda Baumgarten. What Clothes Reveal. p. 118-119; p.123.
} 
opening, loose fit, gored skirts extending from the bodice, and a lack of waist seam. ${ }^{162}$ Bed gowns were short, loose-fitting and comfortable, ideal for hard work. In the 1790s fashionable dress for non-working women dictated the wearing of low cut chemise gowns with a loose fit, and light gauze textiles. ${ }^{163}$ This elite style of dress is consistent with Elizabeth Simcoe's portrait from c.1799 (Figure 3.3). She is displaying the fashion for high and wide hats and hairstyles. Simcoe is not wearing hardy cotton or wool textiles and working-wear while sitting for her portrait, although she might have upon her arrival to Niagara while settling her family into Newark's rudimentary frontier.

During the early days of settlement in Niagara, colonial settlers were divided by lifestyle and class. ${ }^{164}$ However, unlike the imperial countries from which settlers came, Upper Canada's wealthy political elite lived and worked side by side with farming classes in similar domestic conditions. This places early Upper Canada in a unique position in the narrative of lateeighteenth century women's lives. With regards to garments and clothing, upper and labouring class women had relatively the same access to materials through commercial outlets. General stores in Upper Canada sold textiles and ready-made garments supplied by Montreal merchants with imports from Britain. ${ }^{165}$ Through examining clothing and the nature of domestic work in early Upper Canada, this chapter will examine the entangled lives of the upper-middle and labouring class women. It will also analyse the effects of imperial narratives of femininity dispensed through print culture. During the early days of settlement, affluent Upper Canadian colonial women had difficulty replicating the "ideal" societies from which they came. Factors

\footnotetext{
${ }^{162}$ Linda Baumgarten. What Clothes Reveal. P. 123.

${ }^{163}$ Ibid. p. 232.

${ }^{164}$ George Christopher Sheppard. Plunder, Profit, and Paroles .p.34.

${ }^{165}$ Douglas McCalla. Consumers in the Bush: Shopping in Rural Upper Canada. Vol. 3;3. McGill-Queen's University Press, 2015. 44
} 
like a lack of domestic help and scarcity of home supplies contributed to the unique domestic circumstances in which Upper Canadian women found themselves. Adaptability characterized life on the settlement frontier.

In terms of eighteenth century women's clothing, the rich and poor possessed very much the same items. The significant differences lay in quantity, quality and value, making the contrast between clothes owned by the rich and poor markedly apparent, especially in established societies like those in England. ${ }^{166}$ In Sir Frederick Morton's Eden's 1797 study The State of the Poor, he records the clothing expenses for a working woman living in Hertfordshire Parish, England in 1796 (Table 3.1). She would have one petticoat, one apron, two pairs of stockings, one cap, one hat, two shifts, one pair of stays, and a "common stuff gown."167 "Stuff" was a term for a hard-wearing cloth from which working women's gowns were made of. ${ }^{168}$ It was produced from fine, combed wool and woven very firmly. The result was a shiny, glazed scratchy yet durable textile suitable for labouring women's dress and upholstery for furniture. ${ }^{169}$ Figure 3.4 is a later example of a handstitched worsted wool stuff gown dating 1820-30 from the Winterthur Collection. The bodice is fitted, with long narrow sleeves and puffed shoulders and a high neckline, with the high waistline of the neoclassical style. ${ }^{170}$ Working women had access to lower grades of silk, mixtures of linen and wool, and homespun woolens. ${ }^{171}$ Cotton was undeniably "the textile phenomenon of the eighteenth century." 172 It was popular among all classes, indeed textile historian Beverly Lemire credits cotton with bringing fashion to ordinary

\footnotetext{
166 John Styles.The Dress of the People: p.31.

${ }^{167}$ Frederick Morton Eden. The State of the Poor..., III, 1797, reprint (Bristol 1994), p.cccxliii.

${ }^{168}$ Linda Baumgarten. What Clothes Reveal. p. 114.

169 Ibid. p. 114.

170 “Winterthur Museum Collection, 1969.0942” Winterthur Museum Garden and Library. http://museumcollection.winterthur.org (Accessed March 23, 2018).

${ }^{171}$ Linda Baumgarten. What Clothes Reveal p. 115.

172 John Styles.The Dress of the People. p.132.
} 
people. ${ }^{173}$ Colourful printed cotton was the fabric of choice for women's gowns from all levels of society due to its increasing availability (Figures 3.5 and 3.6). Often copying designs from more expensive India chintz, British printed cottons allowed labouring women to engage with fashion. ${ }^{174}$ The British printed textile industry was one of the fastest growing and profitable in the eighteenth century. ${ }^{175}$ By 1840 printed textiles comprised 70 percent of Britain's total exports, making the industry one of the largest in the world. ${ }^{176}$ Many cotton textiles exported to North America have blue threads woven into the selvedges. This is in compliance with an English law dating between 1774 and 1811, ordering three blue threads to be woven into the selvedges of taxed, all-cotton textiles intended for export if the merchants wanted to collect a refund of the tax (Figure 3.8). ${ }^{177}$ British cotton material with blue selvedges can therefore be dated assuredly between 1774 and 1811. In Upper Canada, Mrs. Hannah Jarvis, part of Governor Simcoe's administrative entourage wrote to family in England requesting dark strong printed calico that was "not too fine," 178 presumably for added durability as calicoes and other material were not as easily replaceable on the settlement frontier.

Women in early Upper Canada were makers and menders, but also buyers of clothing. Data collected by in Douglas McCalla in his study Consumers in the Bush: Shopping in Rural Upper Canada, specifically notes women as buyers of seven of the thirty shawls purchased in Yonge Mills between 1808-09, made of muslin or cambric. ${ }^{179}$ Shawls, however, are ready-to-

\footnotetext{
${ }^{173}$ Beverly Lemire Fashion's Favourite: The Cotton Trade and the Consumer in Britain, 1660-1800. Oxford: Oxford University Press, 1992.

${ }^{174}$ Linda Baumgarten. What Clothes Reveal. p. 115.

${ }^{175}$ Eaton, Linda, Florence M. Montgomery, and Henry Francis du Pont Winterthur Museum, Printed Textiles: British and American Cottons and Linens 1700-1850. The Monacelli Press, 2014. p. 17.

${ }^{176}$ Ibid. p. 17.

177 Linda Baumgarten. What Clothes Reveal. P. 49.

${ }^{178}$ Mary Quayle Innis and Elizabeth Simcoe. Mrs. Simcoe's Diary. Toronto: Dundurn Press, 2007. P. 25.

${ }^{179}$ Douglas McCalla. Consumers in the Bush. P.57.
} 
wear special items - everything else clothing maintenance was essential in early Upper Canada. The knowledge of basic sewing skills was very common amongst women of the labouring classes. ${ }^{180}$ In John Styles' study of eighteenth century criminal records in England, there are many references to labouring class women sewing, altering and mending shirts, shifts, handkerchiefs, aprons and caps for their own families. Sewing and mending clothes was seen as the responsibility of women, with single adult men having their clothes mended by the women in their lives even after they left home. ${ }^{181}$ This practice seems to have been the common in Upper Canada. Writing to his father Thomas Ridout ${ }^{182}$ in 1813 from the former village of St. Davids near Niagara-on-the-Lake, Samuel Ridout mentions a Peggy Nelles who "mended my blue coat and sent it down to me for which I thank her very much."183 Marjorie Griffin Cohen's influential study on women's work in Upper Canada characterises Upper Canada's early market economy as colonial, export-oriented and pre-industrial. ${ }^{184}$ It placed strict emphasis on division of labour by gender, with women's labour isolated for production for the household while male labour was centered on production for the market. ${ }^{185}$ Within the Upper Canadian sphere of female labour there were further attempts to divide labour by class. Elite households continually had trouble finding other women who were willing to complete their domestic work for them and not merely

\footnotetext{
180 John Styles.The Dress of the People. p.156.

181 Ibid. p. 156.

182 Thomas Ridout served as Surveyor General in John Graves Simcoe's administration. Burns, Robert J. "Ridout, Thomas" 1987. Dictionary of Canadian Biography. http://www.biographi.ca/en/bio/ridout_thomas_6E.html (Accessed March 3 2018).

183 Samuel Ridout to Thomas Ridout, St. Davids, Upper Canada, August 2nd 1813. F 43 Thomas Ridout Family Fonds, Archives of Ontario, Reel MS 537 (1).

${ }^{184}$ Marjorie Griffin Cohen. Women's Work, Markets, and Economic Development in Nineteenth-Century Ontario. Toronto: University of Toronto Press, 1988. p.23-4.

${ }^{185}$ Ibid. p. 24.
} 
with them. ${ }^{186}$ Seeking servants is reflective of the Upper Canadian elite's early attempts to establish themselves as Canada's aristocracy.

\section{The Elite and "True Womanhood"}

During the early years of colonial settlement in Niagara, women who came from prominent families were met with the challenges of establishing their households on the frontier. Visiting Newark in 1792 and 1793, the author of Canadian Letters described Newark as "a poor, wretched straggling village with a few scattered cottages erected here and there as chance, convenience or caprice dictated... A family accustomed to the conveniences of England must have found this a most uncomfortable abode."187 To ease her discomfort, Mrs. Hannah Jarvis, wife of William Jarvis, the provincial secretary at Newark, very frequently wrote to family in England requesting items and clothing for her family home. She asked for shoes, and for dark strong printed calico, narrow striped red and white cotton for the little girls' gowns, because there was none in Newark and none in Montreal under six shillings a yard. ${ }^{188}$ The Winterthur Collection holds a child's frock of similar description to the ones Mrs. Jarvis requested for her little girls (Figure 3.7). It is a children's frock made of British cotton, dating from around 1790. Easily washable and simply constructed, the frock is designed with practicality in mind. It has 3 adjustable drawstrings, one at the neckline and two on the bodice. Blue thread is sewn into the selvedge, confirming the textiles origin in Britain. ${ }^{189}$ Hannah Jarvis could have sewn a similar design for her children herself.

\footnotetext{
186 Jane Elizabeth Errington. Wives and Mothers, School Mistresses and Scullery Maids. p. 130.

187 Canadian Letters, p. 43. As quoted in Mary Quayle Innis. Mrs. Simcoe's Diary. p.24.

${ }^{188}$ Mary Quayle Innis and Elizabeth Simcoe. Mrs. Simcoe's Diary. p. 25.

${ }^{189}$ Linda Baumgarten. What Clothes Reveal. p. 161.
} 
For the house, Hannah Jarvis requested Britannia metal dessert spoons for her children to use, so as to save her silver ones; camomile flowers, sulphur, castor oil, James's powders ${ }^{190}$ and "some Country Dance Books - you will get them for a shilling a Piece - let them be the Newest and Pretty." ${ }^{191}$ Historian of Upper Canada Jane Errington maintains that at the onset of their arrival to Niagara, elite colonial women were expected to run their households to the standard that their social status and political standing dictated, regardless of the physical conditions or availability of goods and servants in Upper Canada. ${ }^{192}$ Elite women like Hannah Jarvis and Elizabeth Simcoe had more pressing social duties than coping with housework, however their makeshift log houses and canvas tents were wholly unsuitable for receiving guests and officials.

For the women who Amanda Vickery calls the "genteel" class, ${ }^{193}$ a problem deriving from living in a late eighteenth century rudimentary settlement was a combination of the hardships of rural living as well as meeting the expectations placed on women through an AngloProtestant cultural prescription of feminine behaviour. An idea that began rapidly developing around 1780 became known as the idea of "True Womanhood." 194 What was in 1780 an implied expectation was by 1820 solidified in print culture like women's magazines, gift annuals, newspapers and religious literature. ${ }^{195}$ The dictates of feminine behaviour stated that the well being of society predicated on the ability of woman to perform her social and family duties: "A society is constituted on the Domestic and Social Claims on Woman... the true dignity and

\footnotetext{
190 "A febrifuge very popular during the latter part of the 18th century and at the beginning of the 19th; prepared by Dr. Robert James (1703-1776), consisting of one part oxide of antimony and two parts calcium phosphate." "James's Powder, n.". OED Online. January 2018. Oxford University Press. (accessed March 09, 2018).

${ }^{191}$ Mary Quayle Innis and Elizabeth Simcoe. Mrs. Simcoe's Diary. p.25.

192 Jane Elizabeth Errington. Wives and Mothers, School Mistresses and Scullery Maids. p.148.

193 Amanda Vickery. The Gentleman's Daughter: Women's Lives in Georgian England. New Haven, Conn: Yale University Press, 1999. p.1.

${ }^{194}$ Barbara Welter. "The Cult of True Womanhood," American Quarterly 18 (1966): 151-74; ${ }^{194}$ Amanda Vickery. The Gentleman's Daughter. p.3.

195 Amanda Vickery. The Gentleman's Daughter. p.3.
} 
beauty of the female character seem to consist in a right understanding and faithful and cheerful performance of social and family duties."196 To the extent that middle and upper-class women were participating in the print culture of the late-eighteenth early nineteenth centuries, is the extent to which the print culture was "steadily enclosing them within the private sphere of the home." ${ }^{197}$ Errington notes that the idealization of womanhood was included in colonial officials and genteel immigrant's cultural baggage, and also was crucial to defining status. ${ }^{198}$ Class differentiation was a key characteristic of emerging Upper Canadian society. Residents looked to the two imperial centres of Canada, Great Britain and the United States, for guidance in establishing familiar societal protocol.

As noted in Chapter 1, Simcoe and his oligarchy made every effort to establish Britain's institutions on Upper Canadian soil upon his arrival in 1793. These institutions included the attempt at creating a landed aristocracy and a class system as a model that should be followed for the success of society. ${ }^{199}$ As a result, Upper Canadians could be distinguished by class. E.A Talbot, a visitor to Upper Canada, noted this fact, writing: "In Upper Canada, there are only two classes of society. The First is composed of professional men, merchants, civil and military officers, and the members of Provincial Parliament: The Second, of farmers, mechanics and labourers, who associate together on all occasions without any distinction."200 This tale of two classes in Upper Canada is reflected in scholarship on Upper Canadian women. Surviving letters,

\footnotetext{
196 "Domestic and Social Claims on Woman," Mother's Magazine, VI (1846), p.21. As quoted in Barbara Welter. "The Cult of True Womanhood," p.162.

${ }^{197}$ Kathryn Shevelow, Women and Print Culture: The Construction of Femininity in the Early Periodical. London: Routledge, 1989. pp. 5 and I. As quoted in Amanda Vickery, The Gentleman's Daughter p.3.

198 Jane Elizabeth Errington. Wives and Mothers, School Mistresses and Scullery Maids. p. 22.

199 The Editors of Encyclopaedia Britannica. "Constitutional Act" Encyclopaedia Britannica. Encyclopaedia Britannica, inc. 25 July 2013. https://www.britannica.com/event/Constitutional-Act (Accessed February 15, 2018). ${ }^{200}$ E.A. Talbot. Five Years' Residence in the Canadas... 1823. 2 volumes. London: Longman Hurst, 1824. Reprint edition. New York: Johnson Reprint, 1968. As quoted in George Christopher Sheppard. Plunder, Profit, and Paroles: A Social History of the War of 1812 in Upper Canada. McGill-Queen's University Press, 1994. p.33.
} 
diaries and art works by affluent women like Elizabeth Simcoe and Anne Langton present a misleading narrative of life for women in Upper Canada. These histories are exceptional, as most women did not have time to maintain a journal or a substantial family correspondence. And, as Errington notes, the biographies often focus on what set upper-class women apart from their lessaffluent neighbours. ${ }^{201}$

\section{Domestic Labour}

Elizabeth Simcoe wrote to her friend Mrs. Hunt from Niagara in February 1793. After assuring her there are "many feathers, flowers and gauze dresses at our balls (which are every fortnight)," she notes "the greatest inconvenience of this country is want of servants, which are not to be got. The worst of people do you a favour if they merely wash dishes for twenty shillings a month." ${ }^{202}$ Hannah Jarvis had similar complaints: "This is one of the worst places for Servants that can be - they are not to be on any Terms... we cannot get a Woman who can cook a Joint of Meat unless I am at her Heels - and at the price of seven, eight and nine Dollars per month... I have a Scotch girl from the Highlands, Nasty, Sulky, Ill tempered Creture."203 The great "want of servants" in Upper Canada during the early years of settlement was certainly due to working families having to worry about settling into their own homesteads. The social structure was such that women were willing to help other women out with tasks without payment, but not keen on becoming live-in domestic help. ${ }^{204}$

Prominent women like Elizabeth Russell brought servants with her from England to help her settle into her new Niagara home. ${ }^{205}$ Although she had a cook and one other servant,

\footnotetext{
${ }^{201}$ Jane Elizabeth Errington. Wives and Mothers, School Mistresses and Scullery Maids. P.xiv.

202 To Mrs. Hunt, Wolford Lodge, Devonshire, From Elizabeth Simcoe, Newark, February 1793. Elizabeth Simcoe and Mary Quayle Innis. Mrs. Simcoe's Diary. Toronto: Dundurn Press, 2007. pp. 119-120

${ }^{203}$ William Jarvis Papers, Public Archives of Canada, as quoted in Mary Quayle Innis. Mrs. Simcoe's Diary. p.25.

204 Jane Elizabeth Errington. Wives and Mothers, School Mistresses and Scullery Maids. p. 141-142.

205 Ibid. p. 141-142.
} 
Elizabeth wrote to her friend Lizzie Kiernan in January 1793 that she did not have a maidservant, and was thus her families own "Chamber Maid, Housekeeper etc. and [I] am grown quite an expert mantua-maker."206 By necessity, a labour system designated by class could not function efficiently in Upper Canada. Affluent women on the frontier had to complete their own housework and make their own dresses, in the case of Elizabeth Russell, as long as servants were scarce. The problem of finding and keeping servants in Niagara was a continuous problem for affluent families, lasting years. Elizabeth Russell wrote again to Lizzie Kiernan in January 1799 complaining of the high cost of labour and keeping dependable help, saying "a common charwoman" could demand high wages in Niagara. ${ }^{207}$

The "serving classes" who did not see themselves as such, likewise complained of uncongenial mistresses and poor work environments. Writing from Kingston in 1812, "Servita" replied to bitter complaints about servants in larger households, saying: "persons that are under the hard necessity of working for their daily bread in the houses of people no better than themselves are subjected to contumelies, and insults enough without being exposed in printed papers." ${ }^{208}$ In more rural situations, there were different labour practices for women. Instead of "servants" women acted as "help" for other farmer's wives. This arrangement allowed hired help to maintain independence, working with the farmer's wives and not for her. ${ }^{209}$ Helping hands on the farm were desperately needed, and working as a farm hand was a good way to make extra money. As the nineteenth century progressed and towns became more settled, women who were

\footnotetext{
${ }^{206}$ Elizabeth Russell to Lizzie Kiernan, Russell Papers, January 18 1793. As quoted in Jane Elizabeth Errington. Wives and Mothers, School Mistresses and Scullery Maids. p. 141.

${ }^{207}$ Elizabeth Russell to Lizzie Kiernan, Russell Papers, January 26 1799. As quoted in Jane Elizabeth Errington. Wives and Mothers, School Mistresses and Scullery Maids. p. 311.

208 "To the Reckoner," Kingston Gazette, 9 June 1812. As quoted in Jane Elizabeth Errington. Wives and Mothers, School Mistresses and Scullery Maids. P.155.

${ }^{209}$ Jane Elizabeth Errington. Wives and Mothers, School Mistresses and Scullery Maids. p. 108.
} 
skilled mantua makers, dressmakers or milliners found themselves with business opportunities to produce clothing products and sell them out of their homes. ${ }^{210}$ Mrs. Fox from Brockville began to sew "at her home" in $1830 .{ }^{211}$ Errington notes out of total of 71 millinery, hatmaking and dressmaking businesses that placed advertisements in Upper Canadian colonial newspapers between 1815 and 40, nearly 75 percent were from women who seemed to be working alone. ${ }^{212}$ With the challenges of settlement no longer pressing, women with skills were free to pursue business ventures outside of the domestic realm.

The lack of domestic labour available in Upper Canada meant that prominent women worked for the most part, alongside their neighbours in making and mending clothes for their family, food preparation, gardening and household cleaning and laundry. As the nineteenth century progressed and the economy in Upper Canada became more established, elite women were free to emulate the traits of the "true woman" by becoming more involved in their communities. They were "ironically... forced to rely on other women to maintain this."213 Outside of the domestic realm, lower-middle class women found business opportunities making and mending dress items out of their own homes. Within the greater historical narrative of lateeighteenth century women's lives, Upper Canada is a unique case for examination of because of its geographical and political circumstances. In the early days of settlement, the cult of true womanhood by necessity remained within the realm of print culture and did not really take hold until the mid-nineteenth century. ${ }^{214}$ The lives of elite and labouring women were entangled

\footnotetext{
210 Jane Elizabeth Errington. Wives and Mothers, School Mistresses and Scullery Maids. p. 202.

211 Brockville Recorder, 2 November 1830. As quoted in Jane Elizabeth Errington. Wives and Mothers School Mistresses and Scullery Maids. p. 202.

212 Jane Elizabeth Errington. Wives and Mothers, School Mistresses and Scullery Maids. p. 340.

213 Ibid. p. 157.

${ }^{214}$ Jane Elizabeth Errington. Wives and Mothers, School Mistresses and Scullery Maids. Ibid. p. 236.
} 
within the realms of domestic work and hired help until the mid-nineteenth century when the dictates of Victorian society became more concrete.

The reality of rural living and the infrequency of clothing shipments from Britain (only a season from July to November ${ }^{215}$ meant clothing had to be versatile and alterable. Many surviving examples of late-eighteenth century dresses were sewn with stitches that could be easily removed, even in the most expensive and sumptuous gowns. ${ }^{216}$ The Queen's University Collection of Canadian Dress holds a remodelled and adapted cream-coloured dress (Figures 3.9 and 3.10). It is the earliest garment in their collection dating from 1810-1815. It is in the neoclassical style, which preferred high waistlines under the bust, and gowns made of sheer light muslin. Yet the material of the dress is a crisp shiny silk, more consistent with earlier eighteenthcentury styles. Evidence suggests this gown, originally a robe à la Française, was unpicked and re-made into a neoclassical aesthetic consistent with the 1810-1815 date range. ${ }^{217}$ The years of early settlement in Upper Canada spanned the changes in fashion from eighteenth-century mantua to the empire-waist neoclassical gowns. Women aspiring to be fashionable had to adapt to changing styles. Women like Elizabeth Russell or Hannah Jarvis might have employed a skilled dressmaker operating out of her home to remodel an earlier gown from the 1790s, or perhaps even remodelled it herself. The ability to adapt to frontier conditions characterized the domestic and material lives of Upper Canadian women. Whether it was household tasks or mending and making clothes.

\footnotetext{
${ }^{215}$ Mary Holford. "Dress and Society in Upper Canada, 1791-1841." Costume 17, no. 1 (1983): p.78.

216 Linda Baumgarten. What Clothes Reveal. P. 41.

${ }^{217}$ MacKay, Elaine M. Beyond the Silhouette: Fashion and the Women of Historic Kingston. Kingston: Agnes Etherington Art Centre, 2007. p.24
} 


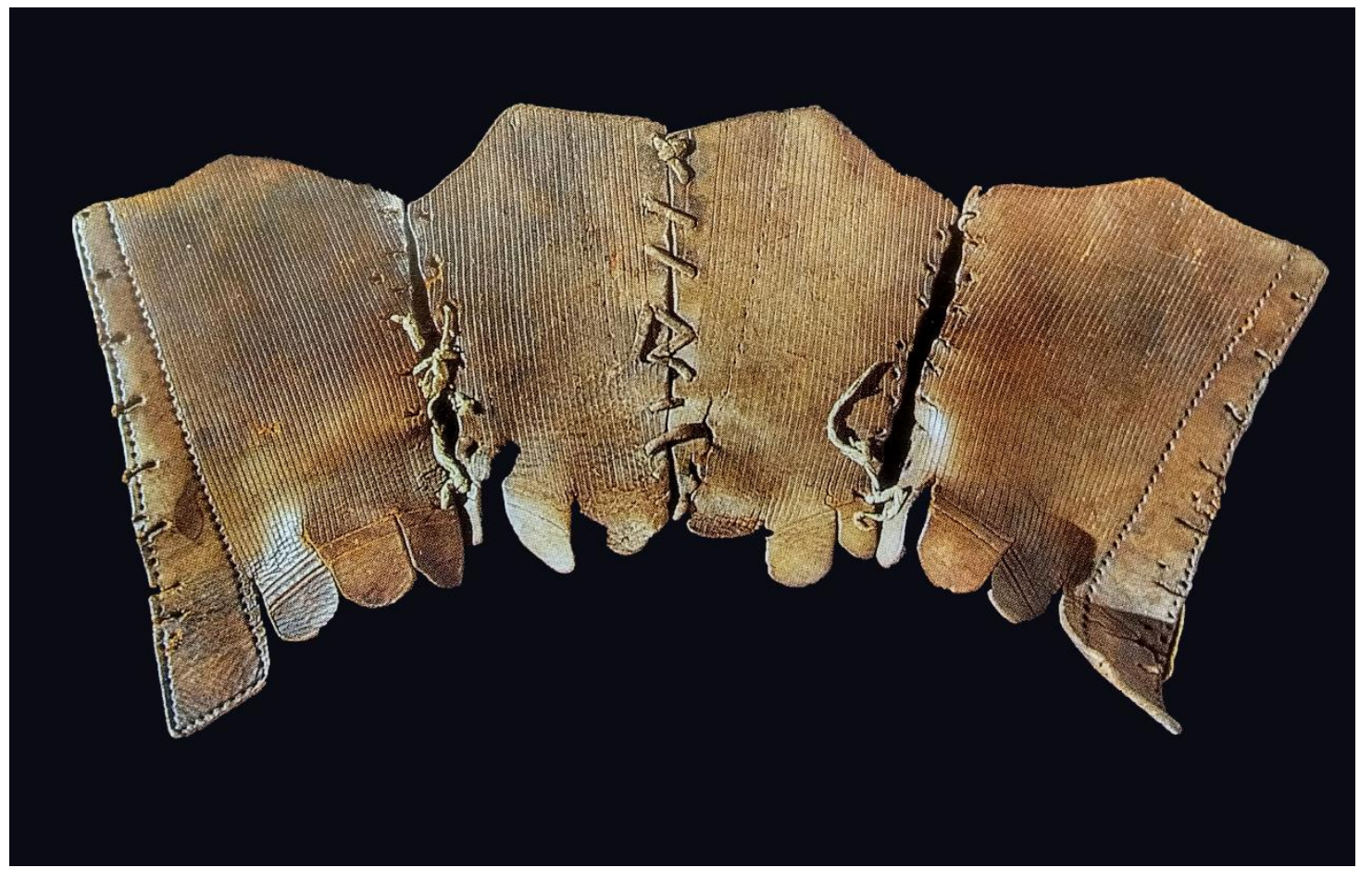

Figure 3.1. Child's leather stays, 1760-1780, Britain. 1993-329. Winterthur Museum Collection, Winterthur. Delaware As reproduced in Linda Baumgarten, What Clothes Reveal: The Language of Clothing in Colonial and Federal America. The Colonial Williamsburg Collection. New Haven: Yale University Press, 2002. p.122. 


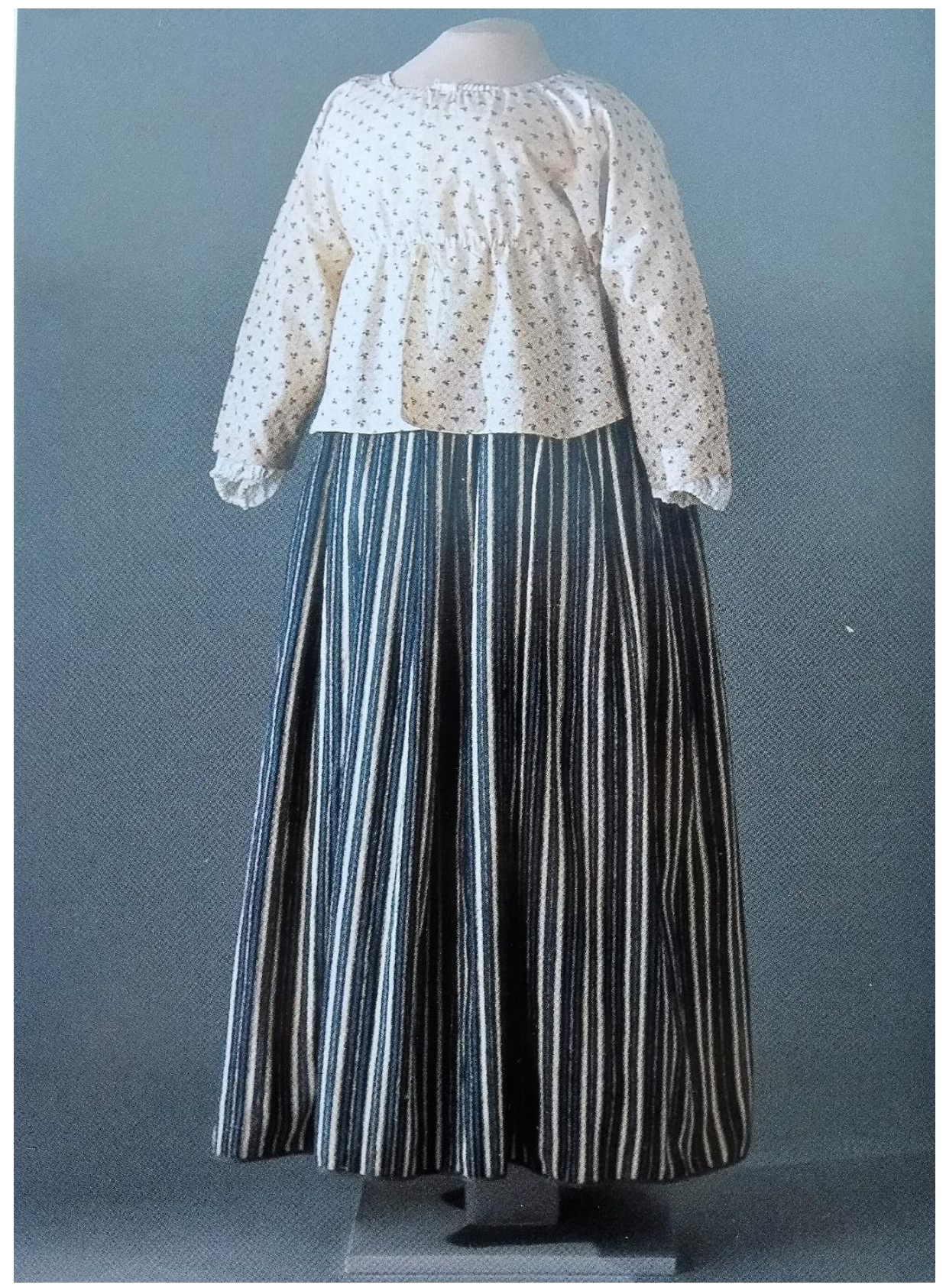

Figure 3.2. Women's work clothing Short gown, America 1800-1820. Roller-printed cotton lined with linen, reproduction shift 1996-95; Petticoat New England or Britain, 1770-1820m linenwool, wool hem binding, linen waistband, 1991-444. Winterthur Museum Collection, Winterthur. Delaware As reproduced in Linda Baumgarten, What Clothes Reveal: The Language of Clothing in Colonial and Federal America. The Colonial Williamsburg Collection. New Haven: Yale University Press, 2002. p.119. 


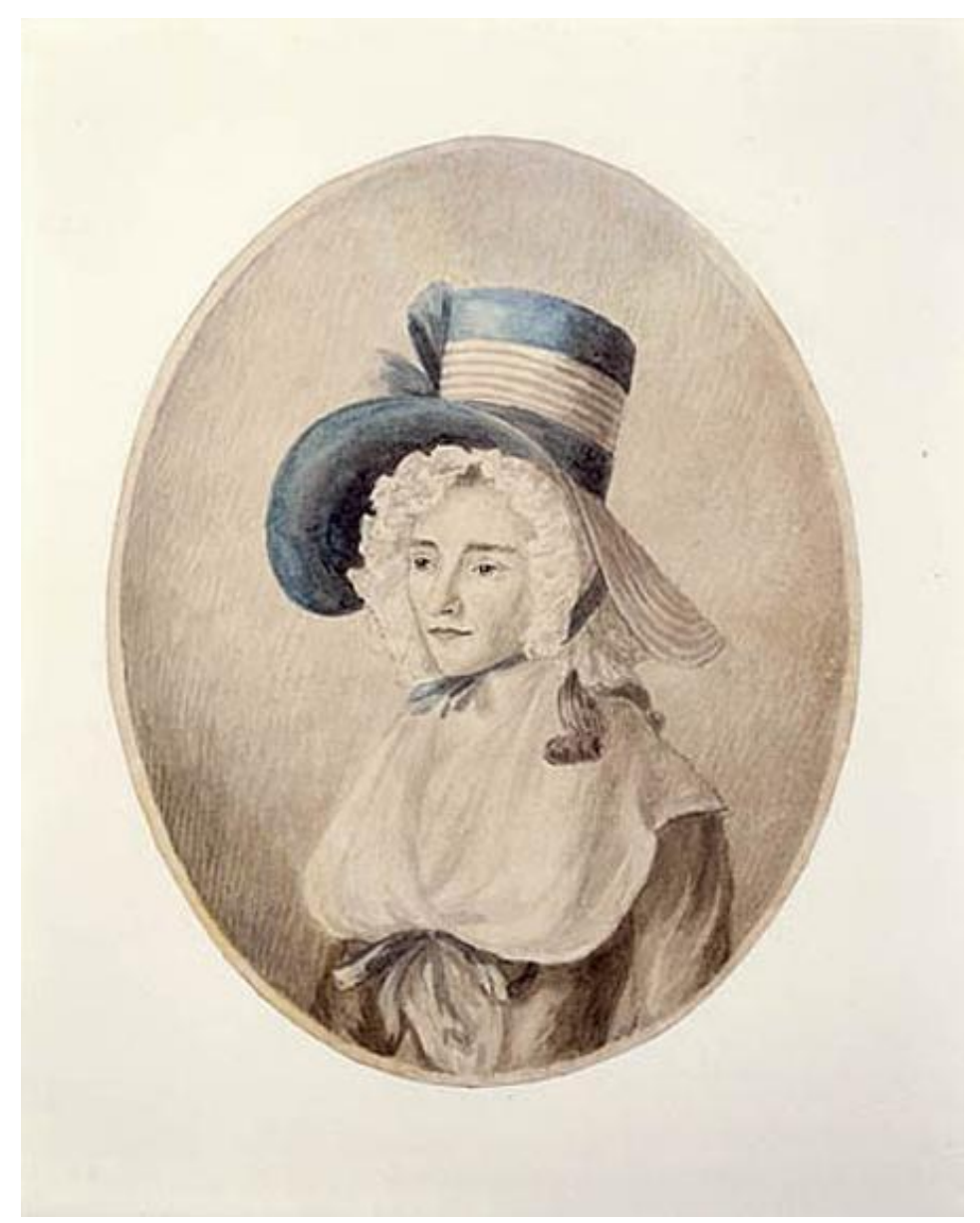

Figure 3.3. Portrait of Elizabeth Posthuma Simcoe, c. 1799, from a watercolour by friend Mary Anne Burgess, Library and Archives Canada. As reproduced in Mary Quayle Innis and Elizabeth Simcoe. Mrs. Simcoe's Diary. Toronto: Dundurn Press, 2007, cover. 


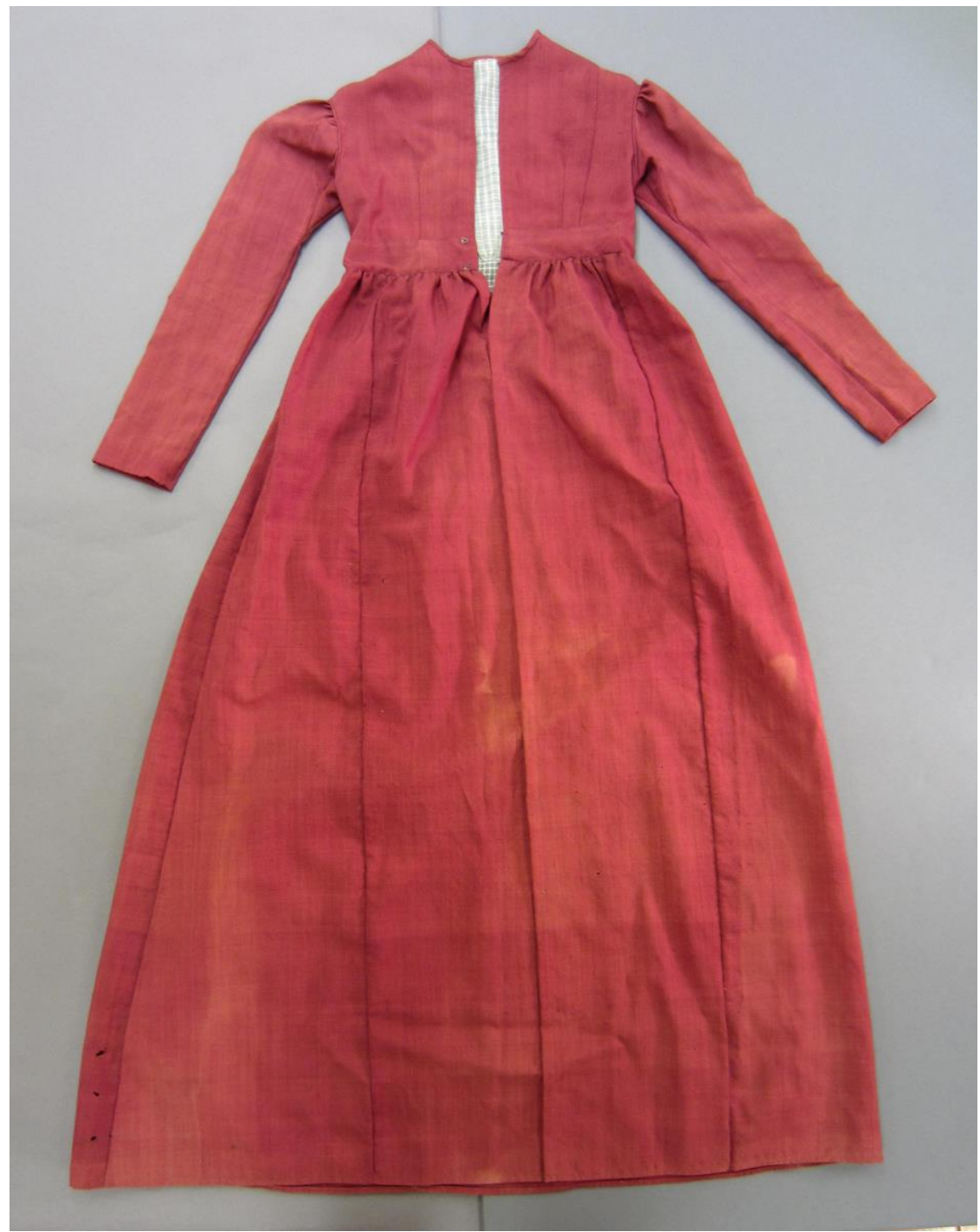

Figure 3.4. Maroon plain-woven worsted wool dress, 1820-1830, United States/North America. Winterthur Museum Collection, Winterthur. Delaware. From: Winterthur Online Catalogue, http://museumcollection.winterthur.org (Accessed March 23, 2018). 


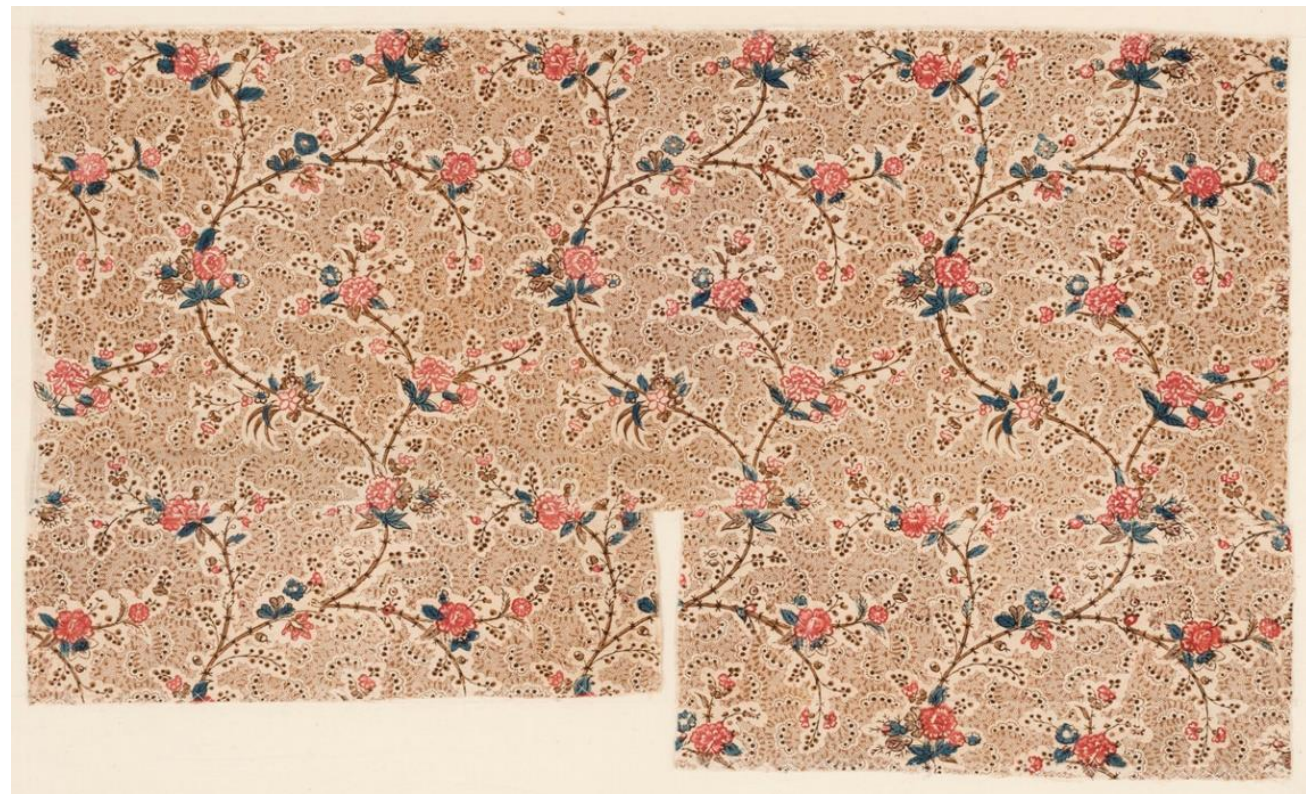

Figure 3.5. Cotton Block Printed Textile, 1770-1790, England, United Kingdom. Winterthur Museum Collection, Winterthur. Delaware. From: Winterthur Online Catalogue, http://museumcollection.winterthur.org (Accessed March 23, 2018).

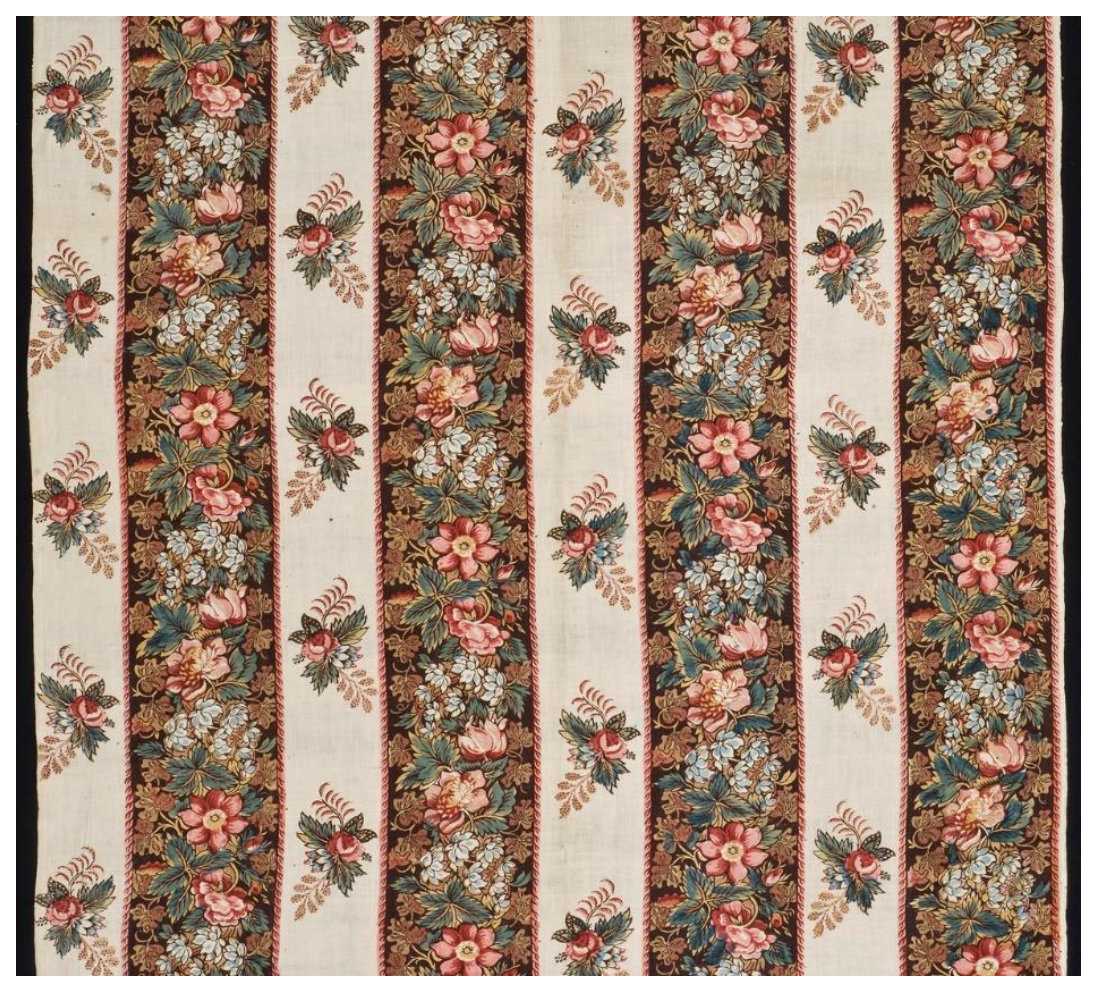

Figure 3.6. Cotton Block Printed Textile, 1790-1800, England, United Kingdom. Winterthur Museum Collection, Winterthur. Delaware. From: Winterthur Online Catalogue, http://museumcollection.winterthur.org (Accessed March 23, 2018). 


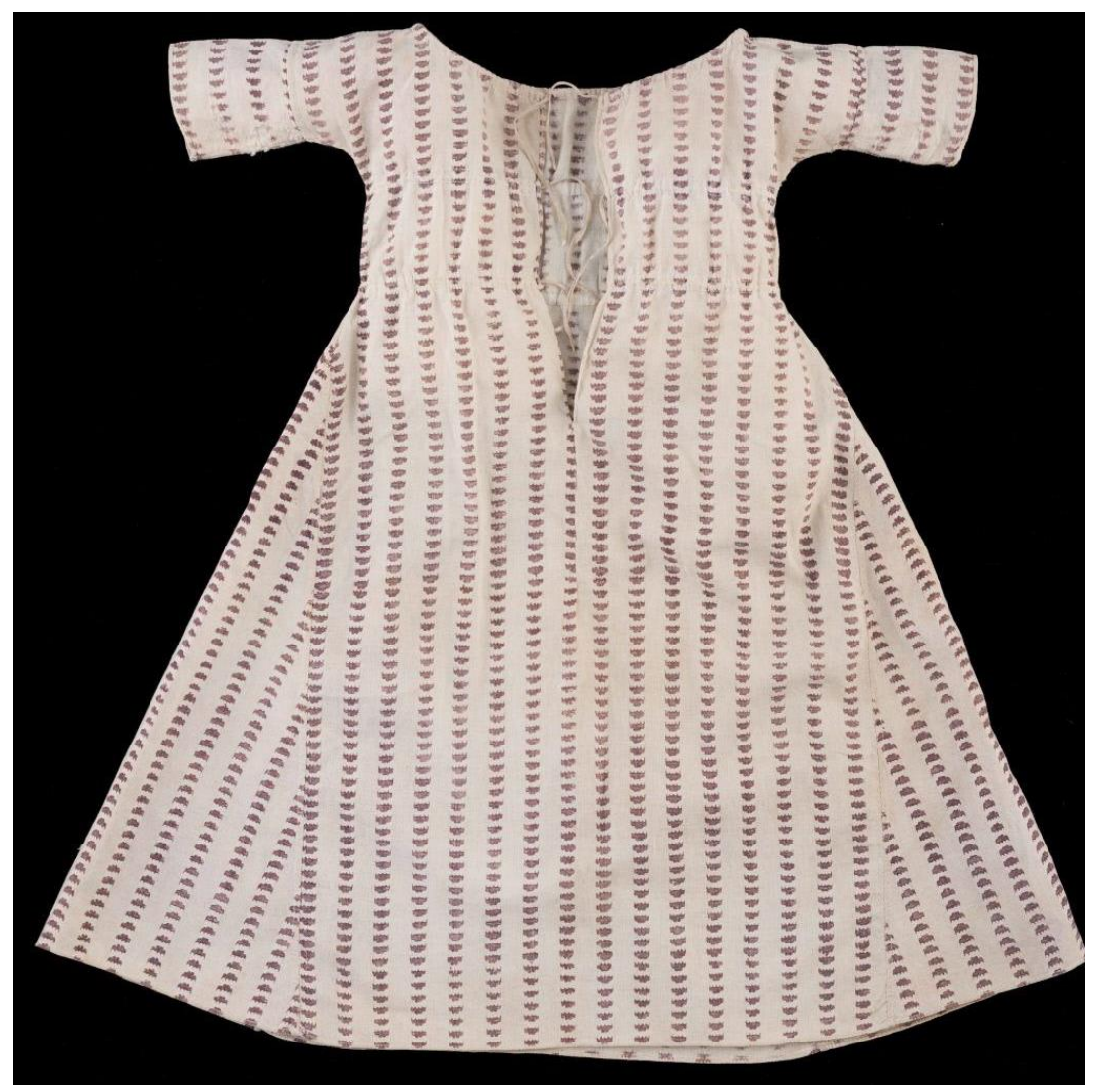

Figure 3.7. Child's Frock, ca. 1790. Cotton manufactured in Britain, worn in America. Winterthur Museum Collection, Winterthur. Delaware. 1992-139. As reproduced in Linda Baumgarten, What Clothes Reveal: The Language of Clothing in Colonial and Federal America. The Colonial Williamsburg Collection. New Haven: Yale University Press, 2002. p.161. 


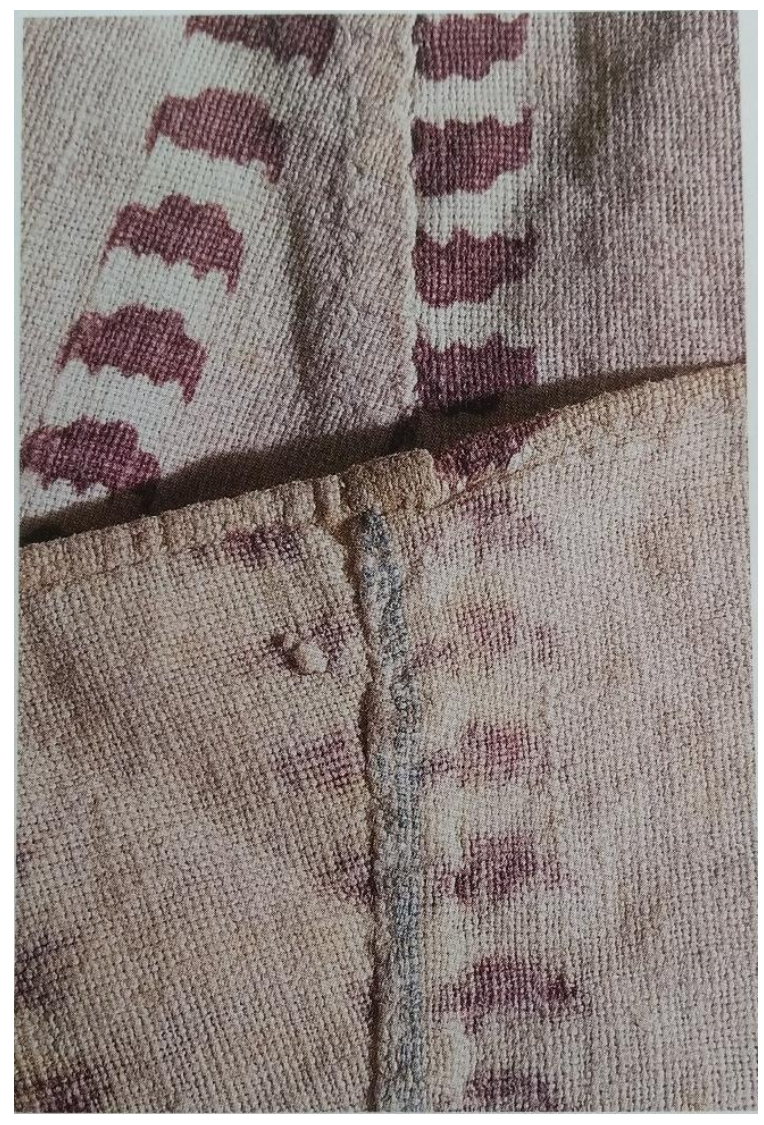

Figure 3.8. Selvedge detail of Child's Frock, ca. 1790. Cotton manufactured in Britain, worn in America. Winterthur Museum Collection, Winterthur. Delaware. 1992-139. As reproduced in Linda Baumgarten, What Clothes Reveal: The Language of Clothing in Colonial and Federal America. The Colonial Williamsburg Collection. New Haven: Yale University Press, 2002. p.161. 


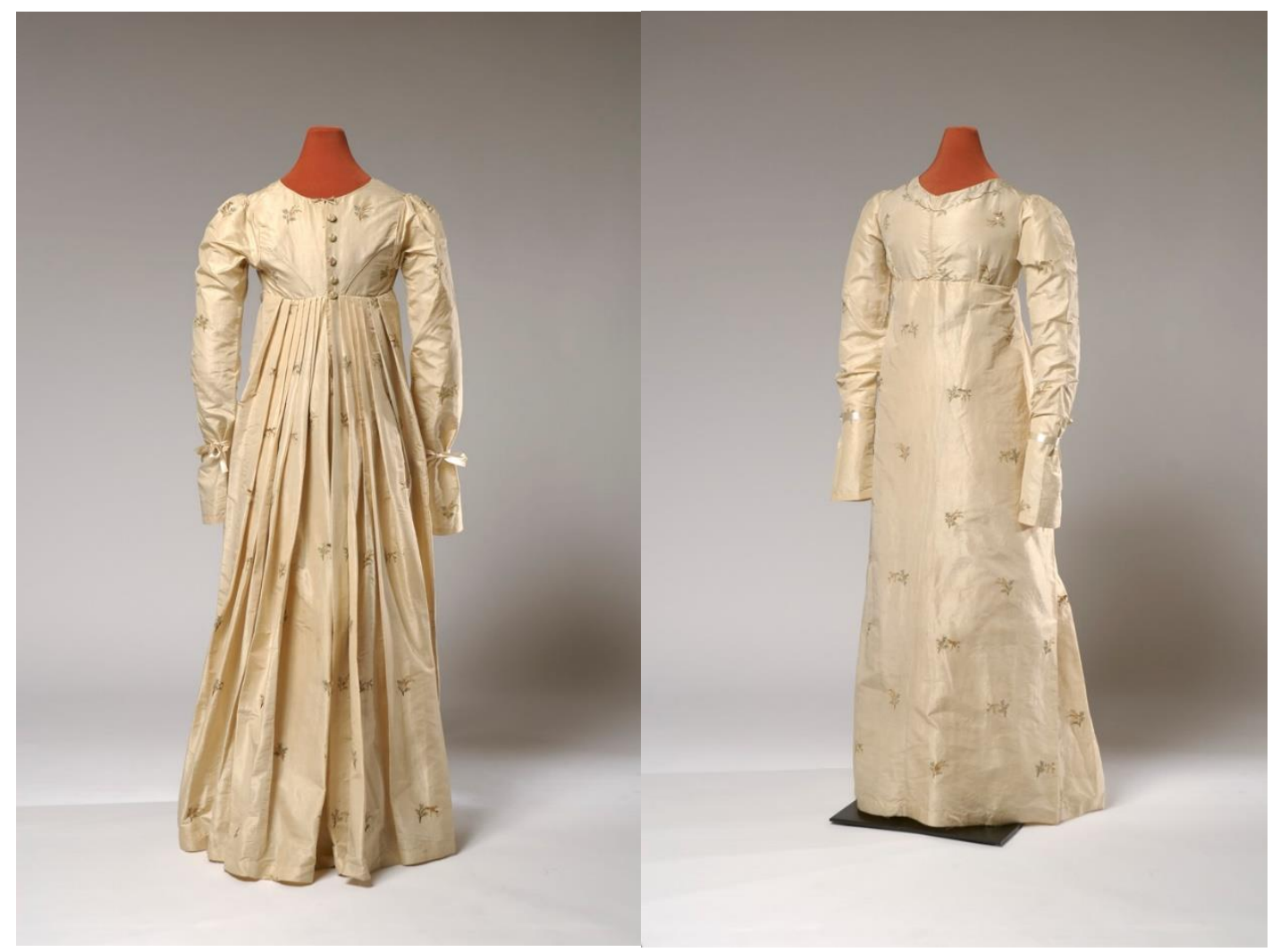

Figures 3.9 \& 3.10. Day Dress, Back (Left) and Front (Right) 1810-1815 silk. Gift of Kathleen Richardson, 1988. C91-719.01 Kingston. Agnes Etherington Art Centre, Queen's University Collection of Canadian Dress, Queen's University, Kingston, Ontario Canada. From: From: Agnes Etherington Online Catalogue, https://agnes.queensu.ca/search-our-collections (Accessed March 24, 2018). 
Table 3.1. The Complete List of the Price of Woman's Clothing for One Year, Hertfordshire Parish, Britain 1796

\begin{tabular}{|c|c|}
\hline Woman. & One Year's Expences. \\
\hline & £. s. d. \\
\hline A common stuff gown & 066 \\
\hline Petticoat & 046 \\
\hline Two Shifts, 3s. 8d. Each i[f] made at home will cost & 060 \\
\hline Two pair of shoes, at $3 \mathrm{~s} .9 \mathrm{~d}$. & 076 \\
\hline Coarse apron, $1 \mathrm{~s}$. Check ditto, $2 \mathrm{~s}$. & 032 \\
\hline 2 pair of stockings, $3 \mathrm{~s}$. If knit at home & 026 \\
\hline Hat, (once in two years,) $1 \mathrm{~s} 8 \mathrm{~d}$. & 0010 \\
\hline Pair of stays, (once in 6 years,) $6 \mathrm{~s}$. & 010 \\
\hline Coloured neck-handkerchief & 010 \\
\hline Two common caps & 018 \\
\hline Cheapest cloak, 2 years, $4 \mathrm{~s} .6 \mathrm{~d}$. & 023 \\
\hline & £. 11611 \\
\hline
\end{tabular}

Source: Frederick Morton Eden. The State of the Poor ..., III, 1797, reprint (Bristol 1994), p.cccxliii. As reproduced in Linda Baumgarten What Clothes Reveal: The Language of Clothing in Colonial and Federal America. The Colonial Williamsburg Collection. New Haven: Yale University Press, 2002. p.245. 


\section{Conclusions and Opportunity for Further Study}

This study is about dress in the lives of early Upper Canadians. It explores themes of Obtainability, Loyalty and Adaptability - three attributes that not only characterised the nature of dress but also early Upper Canadian society. It goes beyond the usual parameters of historical investigation, deeper into the past to get a closer look at the complexities of early settlement history. It also goes further than presenting a typical pioneer narrative, and reveals that even rural Upper Canadians participated in the global consumption patterns of the late eighteenth and early nineteenth centuries. The scope of this study is meant to be a preliminary investigation into the early settler period with room for significant expansion. It is the beginning of the acknowledgement of the complexities of dress in early settler life.

Each of the three chapters in this study presents its own findings. Chapter 1 reveals that textiles and goods related to dress were surprisingly available in town centres and rural villages alike, enhancing the productivity of the household economy. Chapter 2 illustrates how John Graves Simcoe's administration carried the political baggage of eighteenth-century Toryism that contributed to the shaping of Upper Canadian culture in its formative years and upheld conservative attitudes to dress among the elite. Chapter 3 discusses how Upper Canadian settler women were highly adaptable to the domestic circumstances that life on a rural frontier dictated. They made and mended their own clothing and repurposed materials and old dresses as fashionable dress transitioned into neoclassical styles. The overarching conclusion is that relationships to fashion and dress were unexpectedly sophisticated in early Upper Canadian societies between 1790 and 1840. The findings of this MRP contradict romanticized notions of settlers as "isolated, surrounded by the unknown, deprived of the usual supports of civilization, 
and fending for [them] selves." ${ }^{218}$ Archival and material evidence concerning their dress reveal intricacies that beg further unravelling. The early history of Upper Canada holds a unique place in that it is the point of convergence for late-eighteenth century American, British and European contexts. As Alexandra Palmer states "Only by examining this history in its complexity can we begin to assess its significance and impact today and for the future."219

Beginning with the preliminary research conducted in this MRP, there is great potential for a thorough object-based dress history in a more extensive study. In the past, studies of early Canadian history have been limited by the problem of scarcity of sources. Many publications rely on archival sources from Britain and the United States. However, the Archives of Ontario hold the entirety of significant records compiled by the Niagara Historical Society - a more extensive review of the of these collections like the Thomas Ridout (1754-1829) Family Fonds, The Nathan Ford (1763-1829) Family Fonds and the Robert Nelles (1761-1842) Family Fonds, all of whom were landowners in the Niagara in the late eighteenth centuries, would supplement material analyses to a greater degree. Additionally, more time and resources would allow for a more complete cataloguing of the surviving dress examples in museum collections like the Niagara Historical Society, Fort York National Historic Site, Fort George National Historic Site and the Royal Ontario Museum. It would be extremely useful to compile a visual survey of dress in Niagara similar to the one Linda Baumgarten does so well with the Winterthur Museum Collection in her volume What Clothes Reveal: The Language of Clothing in Colonial and Federal America. A doctoral dissertation on early dress in Niagara would be more heavily

\footnotetext{
${ }^{218}$ Douglas McCalla. Consumers in the Bush: Shopping in Rural Upper Canada. Montreal: McGill-Queen's University Press, 2015. P. 8.

${ }^{219}$ Alexandra Palmer. Fashion: A Canadian Perspective. University of Toronto Press. 2004. p.11.
} 
object-based in its analyses, heeding the views of Giorgio Riello and Aileen Ribeiro when they say "historians must integrate the findings derived from the study of material culture into their archive-based and theory-led research...Object or artefacts (what historians calls goods and commodities) need to be used as primary sources." ${ }^{220}$ The larger scope of a long-term study would be able to more clearly delineate the story of dress in the early settler period, incorporating multiple assessments successfully balancing them with a firm focus on objectbased methodologies.

The future of dress studies is one that challenges disciplinary boundaries and helps to reframe them. ${ }^{221}$ It is my hope that this study is a strong example of the potential benefits of a dress history that incorporates methodologies from various fields while highlighting the usefulness of dress as the main method of analyses. With this MRP as well as in future studies, I hope to bring Niagara and early Canadian history to the forefront and encourage further scholarship on the history of dress in Canada.

\footnotetext{
${ }^{220}$ Giorgio Riello. A Foot in the Past. p.6; Aileen Ribeiro, "Re-fashioning Art: Some Visual Approaches to the Study of the History of Dress", Fashion Theory, 2.4 (1998), 315-26.

${ }^{221}$ Francesca Granata. "Fashion Studies In Between: A Methodological Case Study and An Inquiry Into the State of Fashion Studies." Fashion Theory. Volume 16 Issue Berg. 2012. p. 79.
} 


\author{
Bibliography \\ Manuscript Sources
}

\title{
$\underline{\text { Archives of Ontario }}$
}

Gonder Family Fonds, 1796-1850., F 1138-8, reel MS 193/17.

Thomas Ridout Family Fonds, F43, reel MS 537 (1).

Isaac Wilson Diaries, F 1138-H-14, reel MS 199 (5).

\section{Printed Primary Sources}

Canadian Letters, Description of a Tour Thro' the Provinces of Lower and Upper Canada in the Course of the Years 1792 and '93. Montreal, 1912. Reprinted from "The Canadian Antiquarian and Numismatic journal," vol. IX, third series, nos. 3 and 4, July-October, 1912, for Thomas O'Leary.https://archive.org/details/McGillLibrary-130152-5098 (Accessed February 15, 2018)

Cuthbertson, Bennett. A System for the Compleat Interior Management and Oeconomy of a Battalion of Infantry. Dublin, 1768; $2^{\text {nd }}$ ed. Bristol 1776.

"Domestic and Social Claims on Woman," Mother's Magazine, VI, 1846.

Eden, Sir Frederick Morton. The State of the Poor..., III, 1797. Reprint Bristol: Thoemmes, 1994.

Firth, Edith G. The Town of York, 1815-1834: A Further Collection of Documents of Early Toronto. Toronto: Champlain Society, 1966.

Simcoe, Elizabeth, and Mary Quayle. Innis. Mrs. Simcoe's Diary. Toronto: Dundurn Press, 2007.

Strachan, Hew. British Military Uniforms, 1768-1796. The Dress of the British Army from Official Sources. London: Arms and Armour Press, 1975.

Talbot, E.A. Five Years' Residence in the Canadas...1823. 2 volumes. London: Longman Hurst, 1824. Reprint edition. New York: Johnson Reprint, 1968.

\section{Secondary Sources}

Abler, Thomas S. Hinterland Warriors and Military Dress: European Empires and Exotic Uniforms. New York: Berg, 1999.

Baumgarten, Linda, John Watson, and Florine Carr. Costume Close-Up: Clothing Construction and Pattern, 1750-1790. Colonial Williamsburg Foundation, in association with Quite Specific Media Group, New York, 2000.

Baumgarten, Linda and Colonial Williamsburg Foundation. What Clothes Reveal: The Language Of Clothing in Colonial and Federal America. The Colonial Williamsburg Collection, Colonial Williamsburg Foundation, New Haven and London: Yale University Press, 2002. 
Breen, T.H. The Marketplace of Revolution: How Consumer Politics Shaped American Independence . New York: Oxford University Press, 2004

Burns, Robert J. "Ridout, Thomas" 1987. Dictionary of Canadian Biography. http://www.biographi.ca/en/bio/ridout_thomas_6E.html (Accessed March 3 2018).

Careless, J.M.S. Canada: A Story of Challenge. Toronto, 1953.

Creswell, John W. Research Design: Qualitative, Quantitative and Mixed Method Approaches. Thousand Oaks, CA: Sage Publications. 2003.

Cohen, Marjorie Griffin. Women's Work, Markets, and Economic Development in Nineteenth-Century Ontario. Toronto: University of Toronto Press, 1988.

De Marly, Diana. Dress in North America: The New World 1492-1800. New York: Holmes \& Meier, 1990.

Eaton, Linda, Florence M. Montgomery, and Henry Francis du Pont Winterthur Museum, Printed Textiles: British and American Cottons and Linens 1700-1850. The Monacelli Press, 2014.

Editors of Encyclopaedia Britannica. "Constitutional Act” Encyclopaedia Britannica. Encyclopaedia Britannica, inc. 25 July 2013. https://www.britannica.com/event/Constitutional-Act (Accessed February 15, 2018).

Emsley, Clive Tim Hitchcock and Robert Shoemaker. "Currency, Coinage and Cost of Living" Old Bailey Proceedings Online. www.oldbaileyonline.org, version 7.0, 24 (Accessed March 24 2018).

Errington, Jane. The Lion, the Eagle, and Upper Canada: A Developing Colonial Ideology. McGillQueen's University Press, 1994.

-Wives and Mothers, School Mistresses and Scullery Maids: Working Women in Upper Canada 1790-1840. Montreal: McGill-Queen's University Press, 1995.

Fryer, Mary Beacock and Christopher Dracott. John Graves Simcoe, 1752-1806: A Biography. Dundurn Press, 1998.

Granata, Francesca. "Fashion Studies In Between: A Methodological Case Study and An Inquiry Into the State of Fashion Studies." Fashion Theory. Volume 16 Issue Berg. 2012.

Hart, Avril, Leonie Davis, Susan North, Richard Davis, and Victoria and Albert Museum. Historical Fashion in Detail: The 17th and 18th Centuries. London: V\&A Publications, 1998.

"Hessian, adj. and n.1". OED Online. January 2018. Oxford University Press. http://www.oed.com.ezproxy.lib.ryerson.ca/view/Entry/86395?redirectedFrom=hessian+boot (accessed February 27, 2018).

Holford, Mary. "Dress and Society in Upper Canada, 1791-1841." Costume 17, no. 1 (1983): 78-88.

Hood, Adrienne Dora, and David-Thiery Ruddel, "Artifacts and Documents in the History of Quebec Textiles." In Living in a Material World: Canadian and American Approaches to Material 
Culture, edited by Gerald L. Pocius, 55-91. St John's: Institute of Social and Economic Research, Memorial University, 1991.

"James’s Powder, n.". OED Online. January 2018. Oxford University Press.

http://www.oed.com.ezproxy.lib.ryerson.ca/view/Entry/100704?redirectedFrom=James\%27s+po wders (accessed March 09, 2018).

Joseph, Nathan. Uniforms and Nonuniforms: Communication through Clothing. New York: Greenwood 1986.

Knowles, Norman J. Inventing the Loyalists: The Ontario Loyalist Tradition and the Creation of Usable Pasts. University of Toronto Press, 1997.

Laver, James. Modesty in Dress: An Inquiry into the Fundamentals of Fashion, Boston: Houghton Mifflin, 1969.

Lemire, Beverly. Fashion's Favourite: The Cotton Trade and the Consumer in Britain, 1660-1800. Oxford: Oxford University Press, 1992.

Lower, Arthur R. M. Colony to Nation: A History of Canada. Toronto: McClelland and Stewart, 1981.

MacKay, Elaine M. Beyond the Silhouette: Fashion and the Women of Historic Kingston. Kingston: Agnes Etherington Art Centre, 2007.

McCalla, Douglas. Consumers in the Bush: Shopping in Rural Upper Canada. vol. 3;3, McGill-Queen's University Press, 2015.

—_Textile Purchases by Sorte Ordinary Upper Canadians, 1808-1861." Material Culture Review [Online], 53.1 (2001).

Mills, David. The Idea of Loyalty in Upper Canada, 1784-1850 McGill-Queen's University Press, 1988.

Montgomery, Florence M. Textiles in America 1650-1870: A Dictionary Based on Original Documents, Prints and Paintings, Commercial Records, American Merchant's Papers, Shopkeepers'

Advertisements, and Pattern Books with Original Swatches of Cloth. New York: W.W. Norton \& Co., 2007.

Norton, Charles Ledyard, 1837-1909. The Queen's Rangers: a Story of Revolutionary Times. Boston: W.A. Wilde, 1899.

"pipeclay, n.". OED Online. January 2018. Oxford University Press.

http://www.oed.com.ezproxy.lib.ryerson.ca/view/Entry/144386?rskey=nDc1zR\&result=2\&isAd vanced=false (accessed February 17, 2018).

Palmer, Alexandra. Fashion: A Canadian Perspective. University of Toronto Press, 2004.

Read, Colin. Rebellion of 1837 in Upper Canada. Vol. 134 of Carleton Library Series. Ottawa: McGillQueen's Press, 1988.

Ribeiro, Aileen. "Re-fashioning Art: Some Visual Approaches to the Study of the History of Dress" Fashion Theory 2 no. 4 (1998) 315-26. 
—The Art of Dress: Fashion in England and France, 1750-1820. New Haven: Yale University Press, 1995.

Riello, Giorgio. A Foot in the Past: Consumers, Producers and Footwear in the Long Eighteenth Century. Vol. 15. Oxford: Oxford University Press, 2006.

Seccombe, Thomas. "Weld, Isaac (1774-1856)" Oxford Dictionary of National Biography. 2004.

http://www.oxforddnb.com/index/101028984/Isaac-Weld.

Sheppard, George Christopher. Plunder, Profit, and Paroles: A Social History of the War of 1812 in Upper Canada. McGill-Queen's University Press, 1994.

Shevelow, Kathryn. Women and Print Culture: The Construction of Femininity in the Early Periodical. London: Routledge, 1989

Skov, Lisa and Marie Riegels Melchoir. "Research Approaches to the Study of Dress and Fashion." Creative Encounters, Copenhagen, 2008. pp. 1-18.

Stake, Robert E. The Art of Case Study Research. Thousand Oaks, CA: Sage Publications. 1995.

Styles, John. The Dress of the People: Everyday Fashion in Eighteenth-Century England. London: Yale University Press, 2007.

Swainson, Donald. "Street, Thomas Clark (Clarke)" 1972. Dictionary of Canadian Biography. http://www.biographi.ca/en/bio/street_thomas_clark_10E.html (Accessed March 1 2018).

Taylor, Lou. The Study of Dress History. Manchester: Manchester University Press, 2002.

"The Loyalist Collection" UNB Libraries, 2018. University of New Brunswick, https://loyalist.lib.unb.ca/node/4204 (Accessed March 2 2018).

“The Rebels, 1778” American Revolution.Org. Last Modified 2017. http://www.americanrevolution.org/war_songs/warsongs51.php (Accessed February 13, 2018).

"Travels with Elizabeth Simcoe: A Visual Journey Through Upper and Lower Canada." Archives of Ontario. 2012. http://www.archives.gov.on.ca/en/explore/online/simcoe/simcoe-niagara-falls. (Accessed March 26 2018).

Vickery, Amanda. The Gentleman's Daughter: Women's Lives in Georgian England. New Haven, Conn: Yale University Press, 1999.

Welter, Barbara. “The Cult of True Womanhood,” American Quarterly 18 (1966): 151-74.

Willmott, Cory. "From Stroud to Strouds: The Hidden History of a British Fur Trade Textile." Textile History 36, no. 2 (2005): 196-234.

Wilton, Carol. Popular Politics and Political Culture in Upper Canada, 1800-1850. McGill-Queen's University Press, 2000.

Wingate, Isabel B. Fairchild's Dictionary of Textiles, Sixth Edition. New York: Fairchild Publications, 1979. 